\title{
Gas discharges from four remote volcanoes in northern Chile (Putana, Olca, Irruputuncu and Alitar): a geochemical survey
}

\author{
Franco Tassi ${ }^{1,2, \star}$, Felipe Aguilera ${ }^{3,4}$, Orlando Vaselli ${ }^{1,2}$, Thomas Darrah $^{5,6}$, Eduardo Medina $^{7}$ \\ ${ }^{1}$ Università degli Studi di Firenze, Dipartimento di Scienze della Terra, Firenze, Italy \\ ${ }^{2}$ CNR-IGG Istituto di Geoscienze e Georisorse, Firenze, Italy \\ ${ }^{3}$ Universidad de Atacama, Departamento de Geología, Copiapó, Chile \\ ${ }^{4}$ Universidad Católica del Norte, Programa de Doctorado en Ciencias mención Geología, Antofagasta, Chile \\ ${ }^{5}$ University of Rochester, Department of Earth and Environmental Sciences, Rochester, NY, U.S.A. \\ ${ }^{6}$ University of Massachusetts Boston, Department of Environmental, Earth, and Ocean Sciences, Boston, MA, U.S.A. \\ ${ }^{7}$ Universidad Católica del Norte, Departamento de Ciencias Geológicas, Antofagasta, Chile
}

\author{
Article history \\ Received November 23, 2010; accepted March 3, 2011. \\ Subject classification: \\ Fluid geochemistry, Subduction zone, Volcanic risk, Geochemical data, Volcano monitoring.
}

\section{ABSTRACT}

We analyzed gas samples collected from fumaroles and bubbling pools at Irruputuncu, Putana, Olca and Alitar volcanoes located in the central Andes volcanic zone (northern Chile). The Irruputuncu and Putana fumarolic discharges showed outlet temperatures ranging from $83^{\circ} \mathrm{C}$ to $240{ }^{\circ} \mathrm{C}$ and from $82{ }^{\circ} \mathrm{C}$ to $88^{\circ} \mathrm{C}$, respectively. The chemical and isotopic $\left({ }^{3} \mathrm{He} /{ }^{4} \mathrm{He}\right.$, $\delta^{13} \mathrm{C}-\mathrm{CO}_{2}, \delta^{18} \mathrm{O}-\mathrm{H}_{2} \mathrm{O}$ and $\left.\delta \mathrm{D}-\mathrm{H}_{2} \mathrm{O}\right)$ compositions of these discharges were similar to medium-to-high temperature volcanic gases from other active volcanoes in this sector of the Andean volcanic chain (e.g. Lascar volcano). Inorganic and organic gas geothermometers for the $\mathrm{H}_{2} \mathrm{O}-\mathrm{CO}_{2}-\mathrm{CO}-\mathrm{H}_{2}$, $\mathrm{CO}_{2}-\mathrm{CH}_{4}$ and $\mathrm{C}_{2}-\mathrm{C}_{3}$ alkenes-alkanes systems indicated equilibrium temperatures that exceed $500{ }^{\circ} \mathrm{C}$ at the gas sources. These relatively high temperatures are in agreement with the presence of relevantly high concentrations of magmatic gas emissions, including $\mathrm{SO}_{2}$. Olca and Alitar volcano fluid chemistries indicated lower amounts of magmatic-derived gas species, while both the helium and the water isotopic compositions suggested significant fractions of shallow, crustal/meteoric-originated fluids. These indicate contributions from a hydrothermal environment with temperatures $<400{ }^{\circ} \mathrm{C}$. The geochemical and isotopic features derived from the present study show that the Irruputuncu, Putana, Olca and Alitar volcanoes should be considered as active and thus warrant periodic geochemical monitoring to determine the evolution of these systems and their potential hazards.

\section{Introduction}

The central Andean volcanic zone (CAVZ) located in northern Chile is a 1,500-km-long volcanic arc (Figure 1) that originates from when subduction thrust the oceanic Nazca plate beneath the South America plate [de Silva and Francis 1991, Stern 2004], and it includes 44 active or potentially active volcanoes [de Silva 1989a, de Silva 1989b, de Silva and Francis 1991, González-Ferrán 1995, Springer and Förster 1998]. Lascar volcano is considered the most active volcano in the CAVZ [Francis and Rothery 1987, Gardeweg et al. 1998], and its largest historical eruption occurred on April 19-20, 1993 [Gardeweg and Medina 1994]; it is currently characterized by extensive fumarolic activity [Tassi et al. 2009, and references therein]. There are recently documented phreatic to phreato-magmatic events at Isluga, Irruputuncu and San Pedro volcanoes [González-Ferrán 1995, Global Volcanism Program 1997, Céspedes et al. 2004], while there is intense fumarolic activity without recorded historical eruptions at Tacora, Guallatiri, Olca, Ollagüe, Putana, Alítar and Lastarria volcanoes [Casertano 1963, de Silva and Francis 1991, Naranjo 1992, González-Ferrán 1995, Trumbull et al. 1999]. Little is known about the historical eruptions, activities, and/or volcanic structures at Putana, Olca, Irruputuncu and Alitar because of their remote locations and the limited accessibility of these volcanoes.

We present the first analytical data of the chemical and isotopic compositions of the gas discharges (fumaroles and bubbling pools) from Irruputuncu, Olca, Putana and Alitar volcanoes, which were collected during two sampling campaigns in March and May, 2007. The main aims are: (i) to provide the first geochemical and isotopic dataset for the fluids discharged from these volcanoes; and (ii) to investigate the physical-chemical processes that occur between the magmatic source and the shallower hydrothermal aquifers. We also use these geochemical proxies to define a monitoring strategy for these volcanic systems. 


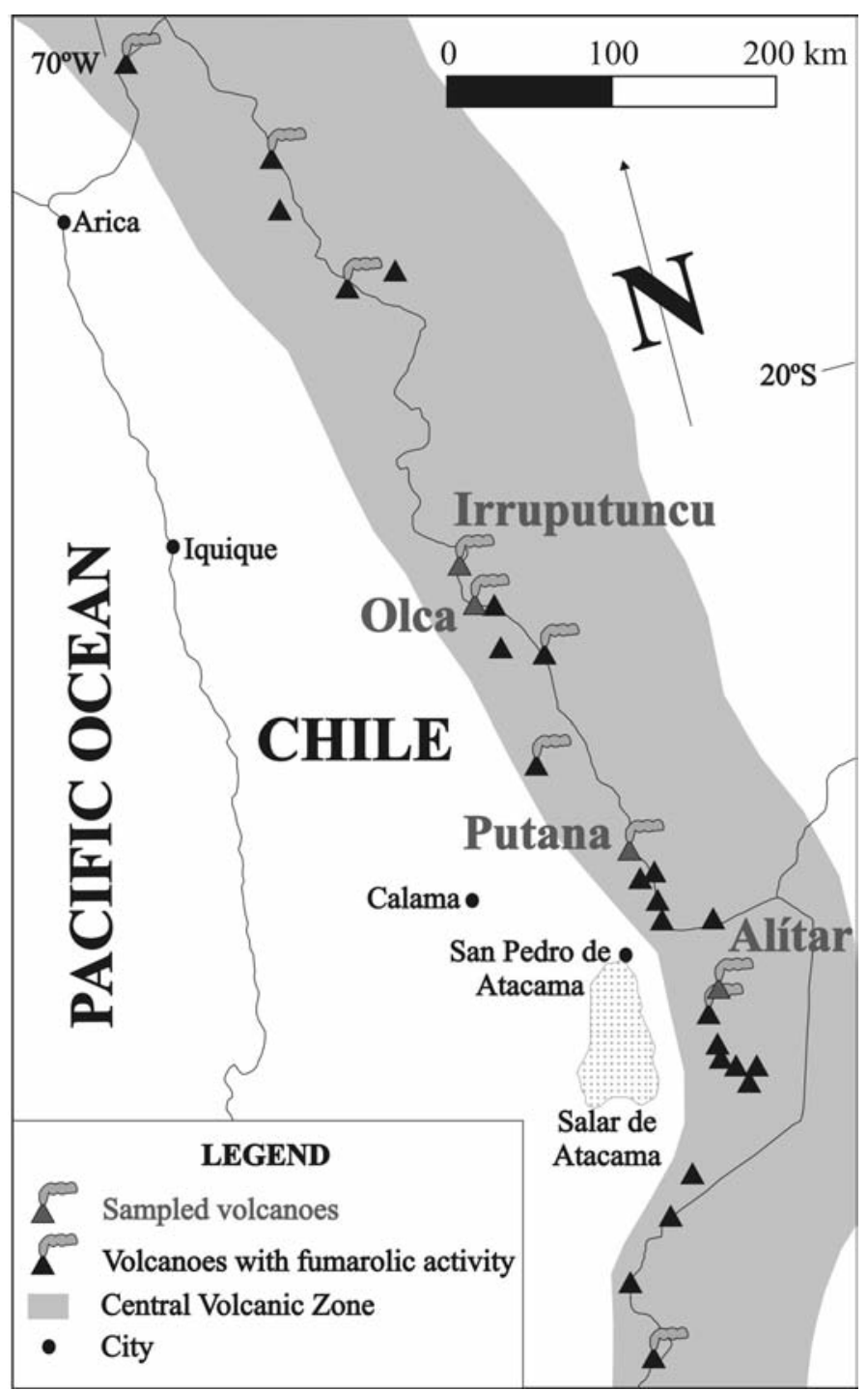

Figure 1. Schematic map of the central volcanic zone of the Andes in northern Chile, with the locations of the Irruputuncu, Olca, Putana and Alitar volcanoes.

\section{Geological setting and volcanic activity (historical and present)}

\subsection{Irruputuncu volcano}

Irruputuncu $\left(20^{\circ} 45^{\prime} \mathrm{S} ; 68^{\circ} 34^{\prime} \mathrm{W} ; 5,165 \mathrm{~m}\right.$ a.s.1.) is a composite stratovolcano that is located at the border between Chile and Bolivia (Figure 1) [de Silva and Francis 1991]. Irruputuncu lies within the SW portion of the collapse scarp from a pre-Holocene volcano [GonzálezFerrán 1995] the products of which cover Upper Miocene-Pleistocene dacitic ignimbrites (Ujina and Pastillos ignimbrites) [Vergara 1978, Vergara and Thomas 1984]. The Irruputuncu cone edifice contains two coalescent summit craters of $\sim 200 \mathrm{~m}$ in diameter (Figure 2) [de Silva and Francis 1991, Wörner et al. 2000]. The cone is primarily composed of andesitic domes with an age of $0.14 \pm 0.04 \mathrm{Ma}$, as indicated by $\mathrm{K}$-Ar dating, and pyroclastic deposits [Wörner et al. 2000]. The most recent historical activity consisted of a series of small phreatic eruptions that produced a 1,000-m-high ash/vapor plume that was observed on November 26, 1995 [Global Volcanism Program 1997]. The current fumarolic activity along the inner SW flank of the southern summit crater produces an $\sim 200$-m-high plume. Recently, local inhabitants reported that a thermal spring located $13 \mathrm{~km}$ west of the volcano [Hauser 1997] disappeared after an earthquake (Mw 7.9) occurred in this area on June 13, 2005.

\subsection{Olca volcano}

Olca $\left(20^{\circ} 57^{\prime} \mathrm{S} ; 68^{\circ} 30^{\prime} \mathrm{W} ; 5,450 \mathrm{~m}\right.$ a.s.1.) is a stratovolcano that forms part of a 20-km-long, EW-oriented volcanic chain that includes Paruma and Michincha volcanoes [de Silva and Francis 1991, González-Ferrán 1995]; it presents strong evidence of past glacial activity along the southern sector (Figure 3). Olca lies above Upper MiocenePliocene dacitic and andesitic volcanic products that form the Ujina ignimbrite [Vergara and Thomas 1984]. Andeciticdacitic lava flows extend up to $7 \mathrm{~km}$ north from the active Olca crater [de Silva and Francis 1991, González-Ferrán 1995, Wörner et al. 2000]. Unconfirmed historical eruptions are suspected to have occurred in 1865-1867 [González-Ferrán 1995], while more recently, anomalous seismic activity hat was most likely related to intense degassing from the volcano summit was recorded in November 1989 and March 1990 [Global Volcanism Program 1990]. The present fumarolic activity of Olca began within the last $\sim 60$ years [Casertano 1963, Global Volcanism Program 1990, Clavero et al. 2006]. At present, the main fumarolic field is restricted to the dome within the summit crater (Figure 3) [Aguilera 2008].

\subsection{Putana volcano}

Putana $\left(22^{\circ} 34^{\prime} \mathrm{S}, 67^{\circ} 52^{\prime} \mathrm{W} ; 5,890 \mathrm{~m}\right.$ a.s.1.) is a stratovolcano with a summit crater of $\sim 0.5 \mathrm{~km}$ in diameter $(\varnothing, \sim 500 \mathrm{~m})$ that consists of two inner craters, one located in its center $(\varnothing \sim 130 \mathrm{~m}$ ), and the other near the NE flank ( $\varnothing$ $\sim 300 \mathrm{~m}$ ) (Figure 4) [González-Ferrán 1995, Aguilera 2008]. The Putana edifice has been built on the andesitic-to-dacitic Pliocene-Pleistocene Tatio and Purificar ignimbrites [Marinovic and Lahsen 1984], and it consists of multiple sequences that include andesitic-basaltic, andesitic and dacitic lavas, and pyroclastic deposits [Marinovic and Lahsen 1984, de Silva and Francis 1991, González Ferrán 1995]. Persistently active degassing from the Putana summit has produced a 100m- to 500-m-high plume since the 19th century [Riso Patrón 1924, Brüggen 1950, Casertano 1963, Deruelle 1979, GonzálezFerrán 1995]. The present survey included the four main active fumarolic fields, known as F1, F2, F3 and F4. The fumarolic field location are (Figure 4): F1, SW sector of the main crater; F2, NW sector of the NE crater; F3, SE sector of the NE crater; F4, NW outer flank of the main crater. Fumarolic vents at Putana volcano range from centimeter fractures to vents of up to $10 \mathrm{~m}$ in diameter, in the F1 and F2 fields. 


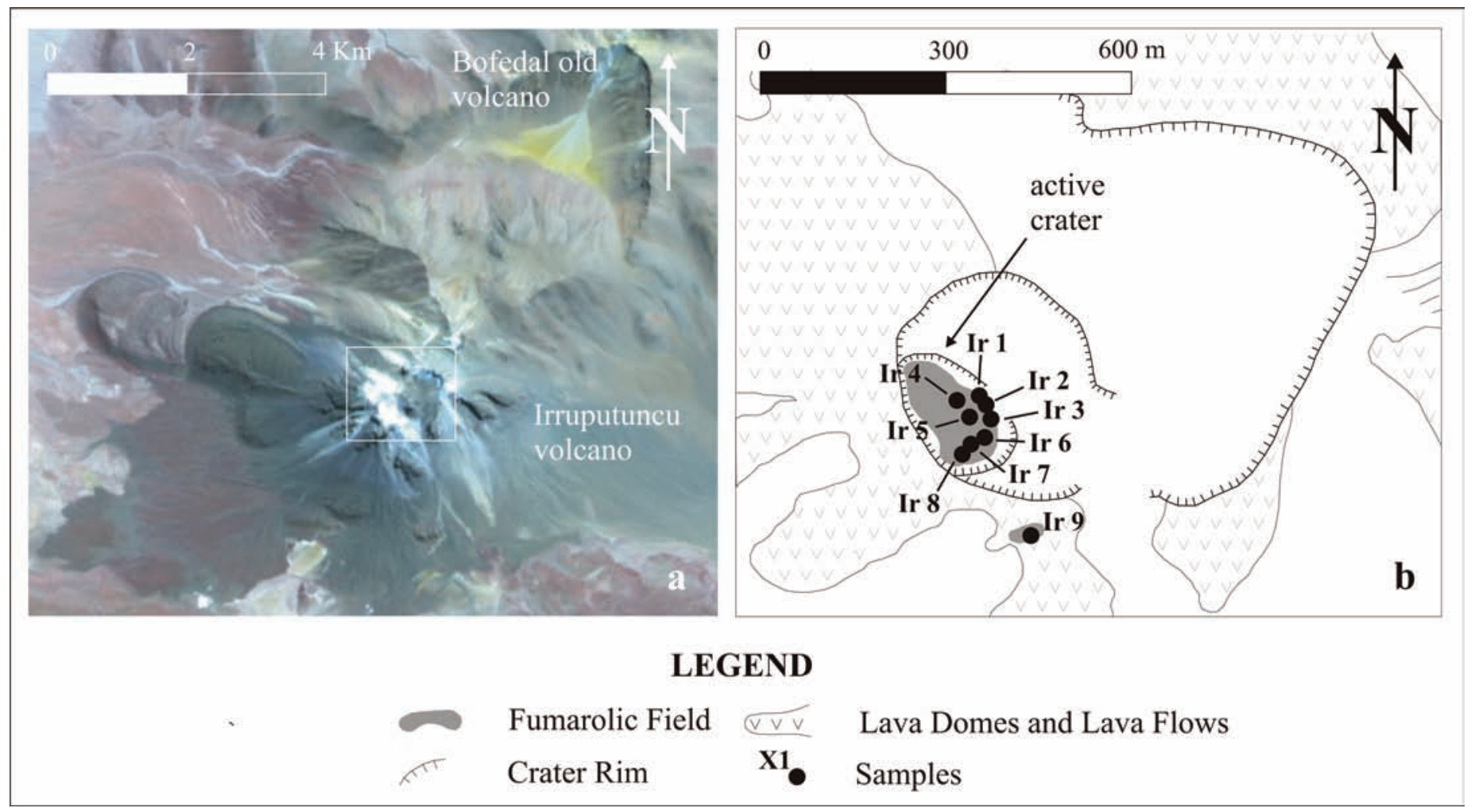

Figure 2. Aerial photograph (a) and schematic map (b) of the summit crater of Irruputuncu volcano, showing the locations of the fumarolic fields and sampling sites.
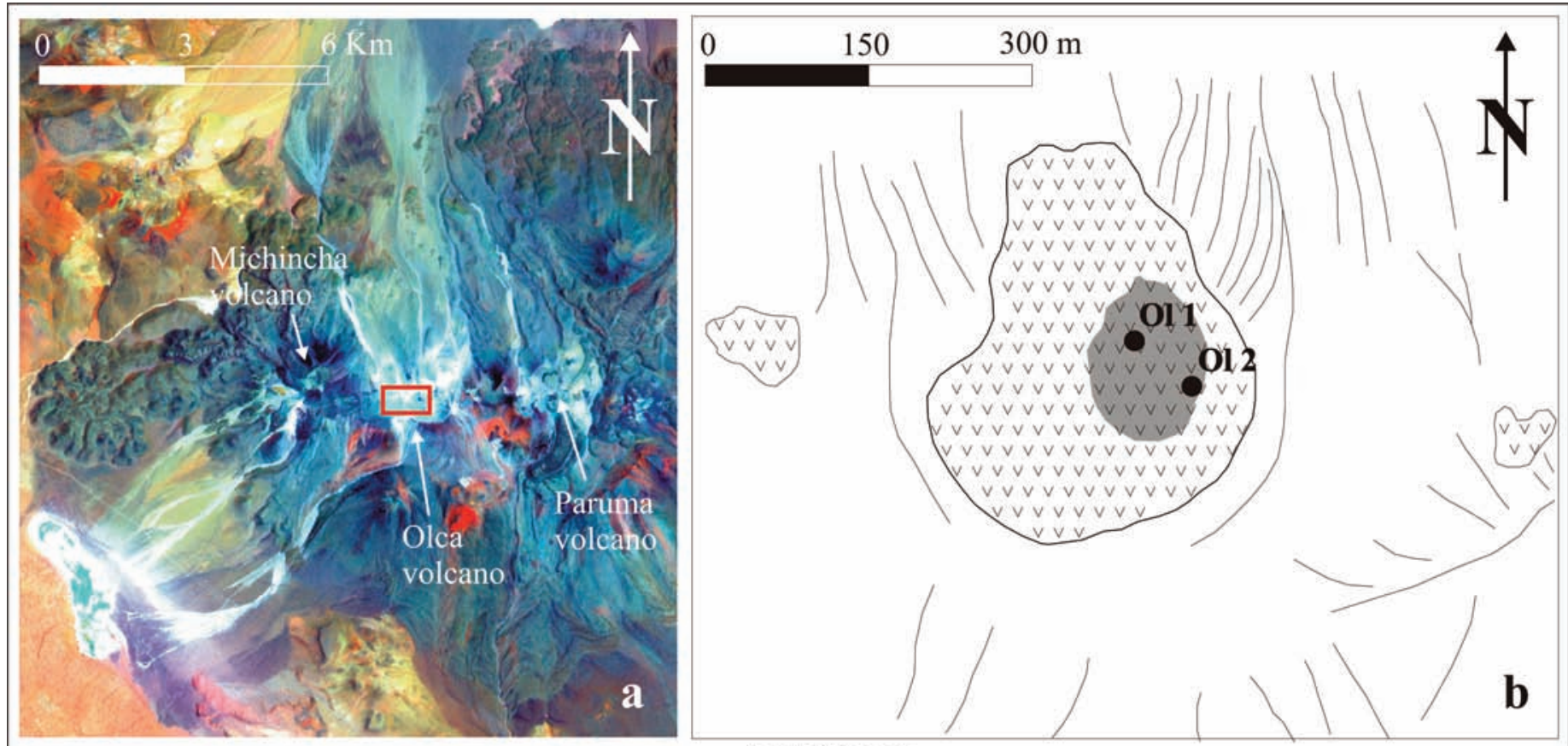

\section{LEGEND}

Fumarolic Field

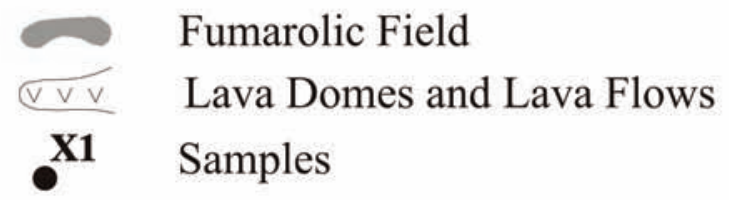

Figure 3. Aerial photograph (a) and schematic map (b) of the summit crater of Olca volcano, showing the locations of the fumarolic fields and sampling sites. 


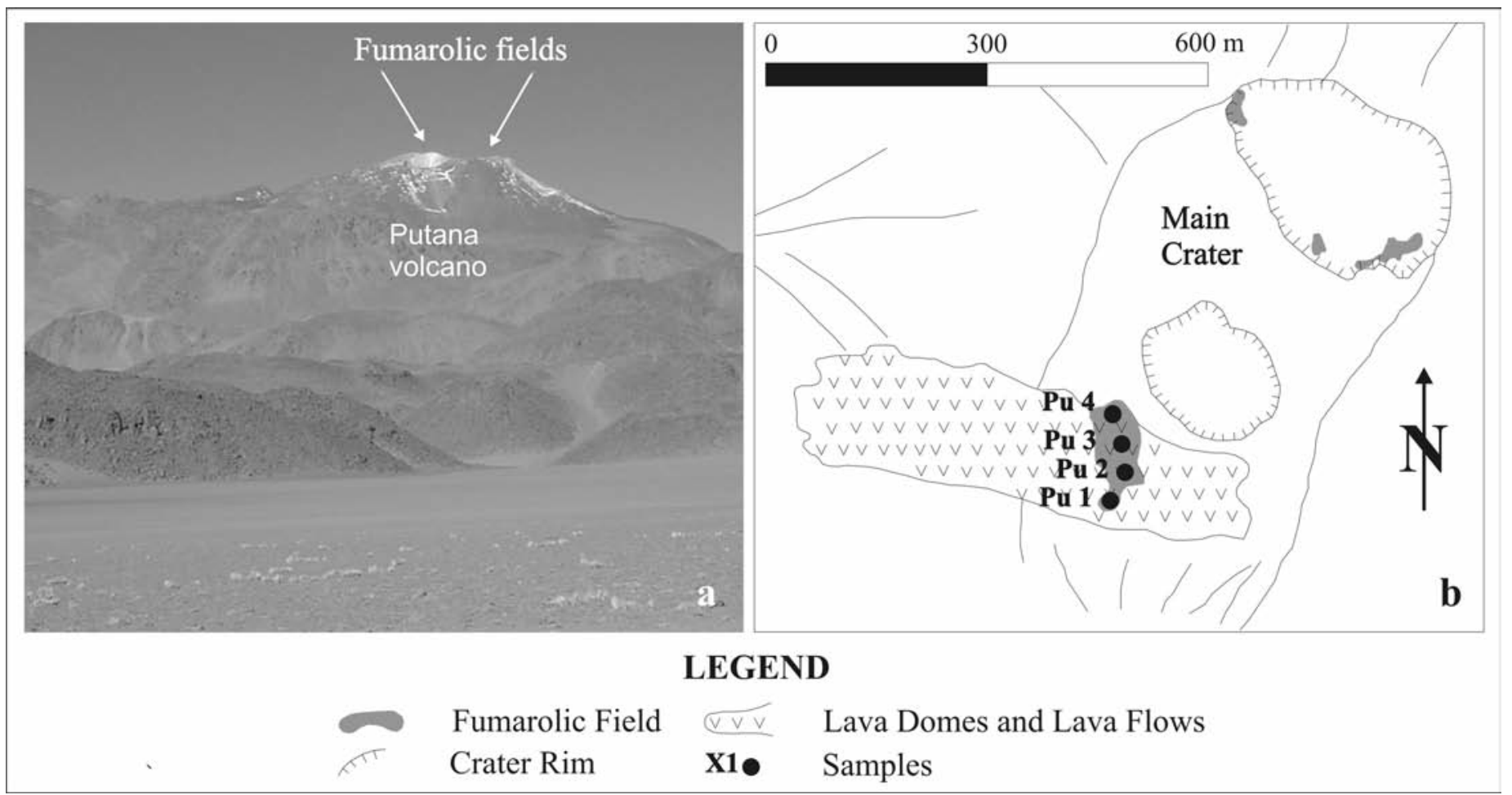

Figure 4. Photograph (a) and schematic map (b) of the summit crater of Putana volcano, showing the locations of the fumarolic fields and sampling sites.

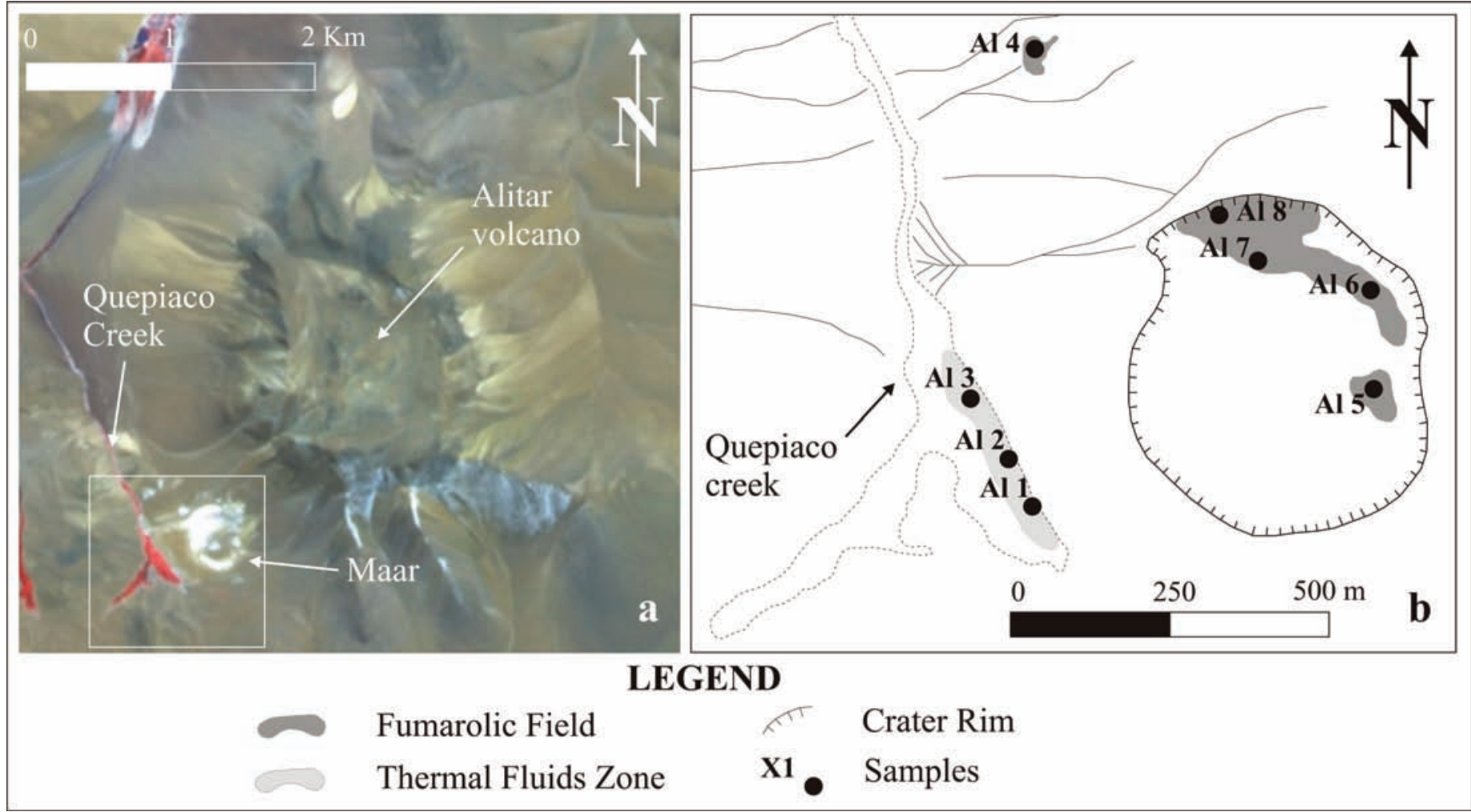

Figure 5. Aerial photograph (a) and schematic map (b) of the summit crater of Alitar volcano, showing the locations of the fumarolic fields and sampling sites. 


\subsection{Alitar volcano}

Alítar $\left(23^{\circ} 09^{\prime} \mathrm{S}, 67^{\circ} 38^{\prime} \mathrm{W} ; 5,346 \mathrm{~m}\right.$ a.s.1.) is a stratovolcano that has a 500-m-wide, 50-m-deep maar (broad, low relief) crater at the base of its SW flank [González-Ferrán 1995] (Figure 5). Alítar has no documented historical activity. The basement of the Alitar volcanic structure consists of Upper Miocene rhyolitic La Pacana ignimbrite and Pliocene dacitic Atana ignimbrite [Ramirez and Gardeweg 1982], and in comparison, the volcanic edifice consists of PliocenePleistocene andesitic-to-dacitic lavas [Ramirez and Gardeweg 1982]. Fumarolic activity has been recognized in the northern sector of the Alitar maar and in a small area $400 \mathrm{~m} \mathrm{NW}$ of the maar (Figure 5). Its current thermal activity also includes six pools that discharge thermal water and gas along a small, NS-oriented creek that is located $\sim 200$ m west of the maar (Figure 5) [Aguilera 2008].

\section{Sampling and analytical methods}

We collected gas samples using a 1-m-long titanium tube $(\varnothing, 2.5 \mathrm{~cm})$ that was inserted into the fumarolic vent and connected through quartz-glass dewar tubes to a preevacuated, 60-mL, glass thorion-tapped flask filled with 20 $\mathrm{mL} 4 \mathrm{~N} \mathrm{NaOH}$ and a $0.15 \mathrm{M} \mathrm{Cd}(\mathrm{OH})_{2}$ suspension [Giggenbach and Goguel 1989, Montegrossi et al. 2001, Vaselli et al. 2006]. We collected aliquots of fumarolic vapor condensates in-line with the main sampling apparatus using an ice-cooled glass tube. The condensate was used to determine $\mathrm{HF}$ concentrations by ion chromatography (Metrohm Basic761) and the $\delta^{18} \mathrm{O}$ and $\delta \mathrm{D}$ isotopic ratios.

We determined the inorganic gases $\left(\mathrm{N}_{2}, \mathrm{O}_{2}, \mathrm{H}_{2}, \mathrm{He}, \mathrm{Ar}\right.$ and $\mathrm{Ne}$ ) in the flask headspace using a Shimadzu 15A gas chromatograph equipped with a 10-m-long $5 \mathrm{~A}$ molecularsieve column and a thermal conductivity detector. We analyzed hydrocarbons, including $\mathrm{CH}_{4}$, using a Shimadzu 14A gas chromatograph equipped with a 10-m-long stainless steel column $(\phi, 2 \mathrm{~mm})$ packed with Chromosorb PAW $80 / 100$ mesh coated with 23\% SP 1700 and a flame ionization detector. Carbon monoxide was analyzed by gas chromatography-flame ionization detection after conversion of $\mathrm{CO}$ to $\mathrm{CH}_{4}$ at $400{ }^{\circ} \mathrm{C}$ using a Shimadzu MTN-1 methanizer.

We separate the alkaline solution from the solid precipitate by centrifugation to determine: 1) $\mathrm{CO}_{2}$, as $\mathrm{CO}_{3}{ }^{2-}$, by titration (Metrohm Basic Titrino) with a $0.5 \mathrm{~N} \mathrm{HCl}$ solution; 2) $\mathrm{SO}_{2}$, as $\mathrm{SO}_{4}{ }^{2-}$, after oxidation with $\mathrm{H}_{2} \mathrm{O}_{2}$; and 3) $\mathrm{HCl}$, as Cl-, by ion chromatography (Metrohm Compact 761). We determined $\mathrm{H} 2 \mathrm{~S}$ by first oxidizing $\mathrm{CdS}$ to $\mathrm{SO}_{4}{ }^{2-}$ with $\mathrm{H}_{2} \mathrm{O}_{2}$, and then using ion chromatography [Montegrossi et al. 2001]. The analytical error was $<5 \%$.

To determine the ${ }^{13} \mathrm{C} /{ }^{12} \mathrm{C}$ isotopic ratio of $\mathrm{CO}_{2}$ (hereafter expressed as $\delta^{13} \mathrm{C}-\mathrm{CO} 2 \% \mathrm{~V}$-PDB), we added $\sim 5$ $\mathrm{mL}$ anhydrous phosphoric acid to $2 \mathrm{~mL}$ of the soda solution under vacuum, and allowed the $\mathrm{CO}_{2}$ emanated to equilibrate at $25 \pm 0.1{ }^{\circ} \mathrm{C}$ in a thermal bath overnight. The extracted $\mathrm{CO}_{2}$ was then purified using liquid $\mathrm{N}_{2}$ and $\mathrm{N}_{2}$-trichloroethylene cryogenic traps, and analyzed using a Finningan Delta $S$ mass spectrometer. We used internal (Carrara and San Vincenzo marbles) and international (NBS18, limestone, and NBS19, carbonate) standards to estimate the external precision. The analytical error and the reproducibility were $\pm 0.05 \%$ and $\pm 0.1 \%$, respectively.

We determined the ${ }^{18} \mathrm{O} /{ }^{16} \mathrm{O}$ and ${ }^{2} \mathrm{H} /{ }^{1} \mathrm{H}$ isotopic ratios of the water vapor (steam) condensates (hereafter expressed as $\delta^{18} \mathrm{O}-\mathrm{H}_{2} \mathrm{O}$ and $\delta \mathrm{D}-\mathrm{H}_{2} \mathrm{O} \% \mathrm{~V}$-SMOW, respectively) using a Finningan Delta Plus XL mass spectrometer at the Geokarst Engineering Laboratory (Trieste, Italy). Oxygen isotopes were analyzed according to the method described by Epstein and Mayeda [1953]. The hydrogen isotopic measurements were conducted on $\mathrm{H}_{2}$ generated by the reaction of $10 \mu \mathrm{L}$ water with metallic zinc at $500{ }^{\circ} \mathrm{C}$, according to the analytical procedure described by Coleman et al. [1982]. We used V-SMOW and SLAP as analytical standards and AR-1 as an internal standard. The analytical error was $\pm 0.1 \%$ and $\pm 0.1 \%$, for $\delta^{18} \mathrm{O}$ and $\delta \mathrm{D}$ values, respectively.

The ${ }^{3} \mathrm{He} /{ }^{4} \mathrm{He}$ (hereafter expressed as $\mathrm{R} / \mathrm{R}_{\mathrm{a}}$ ratios, where $\mathrm{R}$ is the ${ }^{3} \mathrm{He} /{ }^{4} \mathrm{He}$ measured ratio and $\mathrm{R}_{\mathrm{a}}$ is the ${ }^{3} \mathrm{He} /{ }^{4} \mathrm{He}$ ratio of the air: $1.39 \times 10^{-6}$ ) [Mamyrin and Tolstikhin 1984] and ${ }^{40} \mathrm{Ar} /{ }^{36} \mathrm{Ar}$ ratios were determined at the University of Rochester Rare Gas Facility using a VG 5400 rare-gas mass spectrometer fitted with a Faraday cup (resolution, 200) and a Johnston electron multiplier (resolution, 600) for sequential analyses of the ${ }^{4} \mathrm{He}$ (F-cup) and ${ }^{3} \mathrm{He}$ (multiplier) by the method described by Poreda and Farley [1992]. For noble gas isotope analysis, the gas samples were purified in a highvacuum line constructed of stainless steel and Corning-1724 glass to minimize helium diffusion. Water vapor and $\mathrm{CO}_{2}$ were cryogenically trapped at $-90{ }^{\circ} \mathrm{C}$ and $-195{ }^{\circ} \mathrm{C}$, respectively. Nitrogen and $\mathrm{O}_{2}$ were removed with a $\mathrm{Zr}-\mathrm{Al}$ alloy chemical getter (SAES-ST707), whereas Ar and Ne were adsorbed onto activated charcoal at $-196{ }^{\circ} \mathrm{C}$ and at $-233^{\circ} \mathrm{C}$, respectively. SAES-ST-101 getters reduced the $\mathrm{HD}+$ background to $\sim 1,000$ ions/s. We corrected the measured ${ }^{3} \mathrm{He} /{ }^{4} \mathrm{He}$ ratios for the addition of air (monitoring ${ }^{4} \mathrm{He} /{ }^{22} \mathrm{Ne}$ ), by assuming that the fumarolic $\mathrm{Ne}$ is low and of atmospheric origin [Craig and Lupton 1976, Sano and Wakita 1988]. Analytical error for the $\mathrm{R} / \mathrm{R}_{\mathrm{a}}$ determination was $\leq 0.3 \%$. After completing the He isotopic analysis, we analyzed the ${ }^{40} \mathrm{Ar} /{ }^{36} \mathrm{Ar}$ ratios with a VG 5400 mass spectrometer. Sensitivity for the Ar concentrations was about $4 \times 10^{-4}$ Amps/torr on the Faraday cup. Precision for the ${ }^{40} \mathrm{Ar} /{ }^{36} \mathrm{Ar}$ ratios averaged at $0.2 \%$.

\section{Results}

\subsection{Chemical composition of gases}

We present the fumarole characteristics and compositions in Tables 1 and 2, which include outlet 
temperatures, the chemical composition of the dry gas fraction (expressed as $\mathrm{mmol} / \mathrm{mol})$, and gas fraction $\left(\mathrm{X}_{\text {gas }}=\right.$ $\Sigma_{\text {dry gases }} /$ vapor $\left.\times 100\right)$ for gas discharges from Irruputuncu $(9$ fumaroles; Figure 2), Olca (2 fumaroles; Figure 3), Putana (4 fumaroles; Figure 4) and Alitar ( 5 fumaroles and 3 bubbling pools; Figure 5).

Irruputuncu volcano has fumarole outlet temperatures between $83{ }^{\circ} \mathrm{C}$ and $240{ }^{\circ} \mathrm{C}$, while the other three volcanoes have temperatures between $82{ }^{\circ} \mathrm{C}$ and $91{ }^{\circ} \mathrm{C}$. All of the emission temperatures are above or similar to the boiling point for water at 5,000 $\mathrm{m}$ a.s.l. $\left(\sim 83^{\circ} \mathrm{C}\right)$. The temperatures of the Alitar bubbling pools (Al1, Al2 and Al3; Table 1) are between $54{ }^{\circ} \mathrm{C}$ and $57^{\circ} \mathrm{C}$. The fumarolic gas composition is dominated by water vapor $\left(\mathrm{X}_{\text {gas }}\right.$ from $1.45 \%$ to $7.24 \%$ ), while the bubbling gases show $X_{\text {gas }}$ values between $91.9 \%$ and $96.4 \%$. The dry gas fractions are mainly composed of $\mathrm{CO}_{2}$ (from 764 to $983 \mathrm{mmol} / \mathrm{mol}$ ).

At the Irruputuncu and Putana volcanoes, the fumarolic gas species are dominated by relatively high $\mathrm{SO}_{2}$ and $\mathrm{H}_{2} \mathrm{~S}$ concentrations (up to 170 and $52 \mathrm{mmol} / \mathrm{mol}$, respectively), followed in order of abundance by $\mathrm{HCl}, \mathrm{N}_{2}, \mathrm{H}_{2}$ and $\mathrm{HF}$ (up to $14,14,4.0$ and $1.8 \mathrm{mmol} / \mathrm{mol}$, respectively) and then $\mathrm{O}_{2}$, $\mathrm{CO}$, and $\mathrm{CH}_{4}$ (up to $0.41,0.039$, and $0.052 \mathrm{mmol} / \mathrm{mol}$, respectively). The trace concentrations of Ar, He and Ne are lower than $0.039,0.007$ and $0.000021 \mathrm{mmol} / \mathrm{mol}$, respectively. Hydrocarbons are all present at trace levels, with the sum of the seven most-abundant species $<0.0002$ $\mathrm{mmol} / \mathrm{mol}\left(\mathrm{C}_{2} \mathrm{H}_{6}, \mathrm{C}_{2} \mathrm{H}_{4}, \mathrm{C}_{3} \mathrm{H}_{8}, \mathrm{C}_{3} \mathrm{H}_{6}, \mathrm{C}_{4} \mathrm{H}_{4} \mathrm{O}, \mathrm{C}_{6} \mathrm{H}_{6}\right.$ and $\mathrm{C}_{4} \mathrm{H}_{4}$ S; Table 2).

The Olca and Alitar gas compositions vary significantly from the fumaroles of the Irruputuncu and Putana volcanoes. The main differences include: 1) significantly lower concentrations of $\mathrm{H}_{2}, \mathrm{CO}$ and acidic gases (at least one order of magnitude), with the exception of $\mathrm{H}_{2} \mathrm{~S}$ (up to 26 $\mathrm{mmol} / \mathrm{mol})$; 2) significantly higher concentrations of hydrocarbons (including $\mathrm{CH}_{4}$ ) and atmospheric-related (i.e. $\mathrm{O}_{2}, \mathrm{Ar}, \mathrm{Ne}$ ) compounds (up to one order of magnitude). The $\mathrm{N}_{2}$ and He concentrations are between 1.8 to $6.1 \mathrm{mmol} / \mathrm{mol}$ and 0.004 to $0.017 \mathrm{mmol} / \mathrm{mol}$, respectively, and they do not show significant differences from the Irruputuncu and Putana gases. Of note, the $\mathrm{CO}_{2}, \mathrm{CH}_{4}, \mathrm{H}_{2}, \mathrm{CO}$, He and light hydrocarbon concentrations in the dry gas fraction of the Alitar bubbling gases are similar to the other "dry" fumarolic gases at Alitar (Tables 1 and 2), whereas the acidic gases (i.e. $\mathrm{HF}$ and $\mathrm{SO}_{2}$ ) are significantly lower, or even non-detectable.

\subsection{Isotopic compositions of steam $\left(\delta^{18} \mathrm{O}\right.$ and $\left.\mathrm{D}\right)$ and gases} $\left(\mathrm{R} / \mathrm{R}_{a},{ }^{40} \mathrm{Ar} /{ }^{36} \mathrm{Ar}\right.$ and $\left.\delta^{13} \mathrm{C}-\mathrm{CO}_{2}\right)$

Each of the four volcanoes can be clearly distinguished according to the stable isotopic composition $\left(\delta^{18} \mathrm{O}\right.$ and $\left.\delta \mathrm{D}\right)$ of their condensed steam emissions (Table 3 ). The Irruputuncu gas stable isotopic composition is relatively heavy, and it ranges from $\delta^{18} \mathrm{O}:+6.8 \%$ to $+10.4 \%$ and $\delta$ D: $-35.1 \%$ o to $-44.1 \%$ V-SMOW, respectively. From Irruputuncu, the stable isotopic composition of the condensed steam gases are progressively lighter in composition to Putana $\left(\delta^{18} \mathrm{O}\right.$ and $\delta \mathrm{D}: 1.7 \%$ and $-57.2 \% \mathrm{~V}$ SMOW, respectively), Alitar ( $\delta^{18} \mathrm{O}:-1.6 \%$ to $-1.0 \%$ and $\delta \mathrm{D}$ : $-73.4 \%$ to $-67.8 \%$ V-SMOW, respectively) and Olca $\left(\delta^{18} \mathrm{O}\right.$ : $-8.4 \%$ and $-8.0 \%$ and $\delta \mathrm{D}:-97.5 \%$ o to $-95.6 \%$ V-SMOW, respectively). Conversely, our study found no significant differences in the $\delta^{13} \mathrm{C}-\mathrm{CO}_{2}$ values for each of the volcanic

\begin{tabular}{|c|c|c|c|c|c|c|c|c|c|c|c|c|c|c|c|c|c|c|}
\hline & Cord N & Cord E & altitude & $\mathrm{T}\left({ }^{\circ} \mathrm{C}\right)$ & $\mathrm{CO}_{2}$ & $\mathrm{HCl}$ & $\mathrm{HF}$ & $\mathrm{SO}_{2}$ & $\mathrm{H}_{2} \mathrm{~S}$ & $\mathrm{~N}_{2}$ & $\mathrm{CH}_{4}$ & $\mathrm{Ar}$ & $\mathrm{O}_{2}$ & $\mathrm{Ne}$ & $\mathrm{H}_{2}$ & $\mathrm{He}$ & $\mathrm{CO}$ & $\mathrm{X}_{\text {gas }} \%$ \\
\hline $\operatorname{Ir} 1$ & 7706213 & 545020 & 4976 & 89 & 890 & 6.7 & 1.2 & 77 & 12 & 11 & 0.007 & 0.007 & 0.02 & 0.000004 & 2.1 & 0.005 & 0.020 & 2.05 \\
\hline Ir 2 & 7707197 & 546043 & 4978 & 86 & 901 & 6.4 & 1.2 & 66 & 13 & 8.9 & 0.010 & 0.006 & 0.02 & 0.000004 & 2.4 & 0.005 & 0.024 & 2.47 \\
\hline Ir 3 & 7707196 & 546059 & 4983 & 95 & 895 & 7.0 & 1.0 & 65 & 19 & 10 & 0.008 & 0.008 & 0.03 & 0.000005 & 2.6 & 0.006 & 0.024 & 2.23 \\
\hline Ir 4 & 7707172 & 546041 & 4984 & 176 & 873 & 6.1 & 1.0 & 88 & 25 & 5.1 & 0.002 & 0.005 & 0.02 & 0.000003 & 2.9 & 0.004 & 0.026 & 3.95 \\
\hline $\operatorname{Ir} 5$ & 7707172 & 546046 & 4984 & 240 & 793 & 14 & 1.8 & 170 & 10 & 10 & 0.009 & 0.009 & 0.02 & 0.000005 & 2.2 & 0.004 & 0.027 & 2.57 \\
\hline $\operatorname{Ir} 6$ & 7707168 & 546046 & 4984 & 83 & 895 & 4.3 & 0.8 & 60 & 29 & 7.0 & 0.022 & 0.008 & 0.03 & 0.000005 & 4.0 & 0.006 & 0.021 & 2.51 \\
\hline $\operatorname{Ir} 7$ & 7707192 & 545906 & 4984 & 169 & 867 & 9.1 & 0.9 & 92 & 20 & 8.4 & 0.007 & 0.006 & 0.04 & 0.000004 & 2.0 & 0.006 & 0.023 & 2.65 \\
\hline Ir 8 & 7707167 & 546022 & 4984 & 202 & 809 & 13 & 1.8 & 147 & 18 & 7.1 & 0.003 & 0.006 & 0.05 & 0.000003 & 3.3 & 0.006 & 0.031 & 2.41 \\
\hline $\operatorname{Ir} 9$ & 7706968 & 546118 & 4986 & 85 & 879 & 5.5 & 0.9 & 77 & 20 & 14 & 0.011 & 0.011 & 0.02 & 0.000006 & 3.2 & 0.007 & 0.022 & 2.26 \\
\hline Ol 1 & 7684268 & 553718 & 5353 & 91 & 972 & 1.5 & 0.05 & 6.4 & 15 & 4.5 & 0.11 & 0.007 & 0.01 & 0.000004 & 0.48 & 0.007 & 0.002 & 3.17 \\
\hline 이 2 & 7684227 & 553781 & 5316 & 84 & 972 & 1.8 & 0.07 & 6.3 & 16 & 3.3 & 0.16 & 0.006 & 0.01 & 0.000003 & 0.60 & 0.008 & 0.001 & 3.05 \\
\hline Pu 1 & 7504900 & 617400 & 5800 & 88 & 950 & 5.5 & n.a. & 26 & 8.5 & 7.0 & 0.052 & 0.039 & 0.41 & 0.000021 & 2.2 & 0.005 & 0.038 & 7.24 \\
\hline Pu 2 & 7504757 & 617478 & 5745 & 82 & 941 & 9.0 & 1.0 & 37 & 6.3 & 2.5 & 0.025 & 0.003 & 0.02 & 0.000002 & 3.1 & 0.003 & 0.037 & 5.50 \\
\hline Pu 3 & 7504757 & 617478 & 5745 & 82 & 932 & 9.1 & 1.4 & 44 & 7.9 & 3.1 & 0.037 & 0.003 & 0.02 & 0.000002 & 2.1 & 0.003 & 0.039 & 4.85 \\
\hline $\mathrm{Pu} 4$ & 7504757 & 617478 & 5745 & 83 & 923 & 10 & 1.4 & 53 & 6.5 & 2.5 & 0.022 & 0.002 & 0.02 & 0.000001 & 3.1 & 0.005 & 0.039 & 4.42 \\
\hline Al 1 & 7439687 & 637540 & 4713 & 57 & 983 & 0.03 & $<0.001$ & $<0.001$ & 1.2 & 14 & 0.62 & 0.137 & 0.55 & 0.000070 & 0.25 & 0.008 & 0.0005 & 96.4 \\
\hline $\mathrm{Al} 2$ & 7439747 & 637491 & 4716 & 54 & 982 & 0.03 & $<0.001$ & $<0.001$ & 1.3 & 15 & 0.54 & 0.141 & 0.46 & 0.000083 & 0.17 & 0.011 & 0.0005 & 91.9 \\
\hline Al 3 & 7439962 & 637390 & 4714 & 54 & 981 & 0.03 & $<0.001$ & $<0.001$ & 1.2 & 17 & 0.54 & 0.137 & 0.45 & 0.000072 & 0.21 & 0.009 & 0.0005 & 94.5 \\
\hline Al 4 & 7440380 & 637570 & 4743 & 85 & 977 & 0.75 & 0.006 & 2.5 & 12 & 6.1 & 0.62 & 0.008 & 0.03 & 0.000005 & 0.65 & 0.017 & 0.0018 & 1.64 \\
\hline Al 5 & 7439870 & 638071 & 4768 & 85 & 977 & 0.86 & 0.034 & 3.3 & 15 & 3.1 & 0.45 & 0.003 & 0.02 & 0.000002 & 0.41 & 0.004 & 0.0011 & 1.92 \\
\hline Al 6 & 7439978 & 638087 & 4786 & 85 & 976 & 0.80 & 0.015 & 2.7 & 17 & 2.7 & 0.36 & 0.005 & 0.02 & 0.000003 & 0.33 & 0.005 & 0.0007 & 1.91 \\
\hline Al 7 & 7440047 & 637886 & 4756 & 85 & 963 & 0.69 & 0.024 & 3.2 & 26 & 5.9 & 0.27 & 0.007 & 0.03 & 0.000004 & 0.54 & 0.006 & 0.0007 & 1.76 \\
\hline Al 8 & 7440066 & 637833 & 4766 & 85 & 974 & 0.81 & 0.012 & 3.7 & 18 & 1.8 & 0.24 & 0.002 & 0.02 & 0.000001 & 0.59 & 0.007 & 0.0016 & 1.45 \\
\hline
\end{tabular}

Table 1. Outlet temperatures, chemical compositions (dry gas fractions) and Xgas ( $\Sigma_{\text {dry gases }} /$ steam in \%) of fumaroles from the fumaroles of Irruputuncu (Ir), Olca (Ol), Putana (Pu) and Alitar (Al) volcanoes. Concentrations of gas compounds are in $\mathrm{mmol} / \mathrm{mol}$; n.a.: not analyzed. 


\begin{tabular}{|c|c|c|c|c|c|c|c|c|c|}
\hline & $\mathrm{C}_{2} \mathrm{H}_{6}$ & $\mathrm{C}_{2} \mathrm{H}_{4}$ & $\mathrm{C}_{3} \mathrm{H}_{8}$ & $\mathrm{C}_{3} \mathrm{H}_{6}$ & $\mathrm{C}_{4} \mathrm{H}_{4} \mathrm{O}$ & $\mathrm{C}_{6} \mathrm{H}_{6}$ & $\mathrm{C}_{4} \mathrm{H}_{4} \mathrm{~S}$ & $T_{\mathrm{C} 2-\mathrm{C} 2}$ & $T_{\mathrm{C}_{3-\mathrm{C}}}$ \\
\hline $\operatorname{Ir} 1$ & 0.000029 & 0.000004 & 0.000006 & 0.000011 & 0.000014 & 0.000033 & 0.000006 & 501 & 478 \\
\hline Ir 2 & 0.000024 & 0.000003 & 0.000005 & 0.000008 & 0.000016 & 0.000026 & 0.000009 & 514 & 495 \\
\hline Ir 3 & 0.000018 & 0.000003 & 0.000006 & 0.000010 & 0.000015 & 0.000021 & 0.000011 & 514 & 486 \\
\hline Ir 4 & 0.000019 & 0.000002 & 0.000004 & 0.000006 & 0.000016 & 0.000012 & 0.000020 & 523 & 528 \\
\hline Ir 5 & 0.000025 & 0.000003 & 0.000005 & 0.000007 & 0.000029 & 0.000019 & 0.000008 & 505 & 487 \\
\hline $\operatorname{Ir} 6$ & 0.000037 & 0.000004 & 0.000007 & 0.000010 & 0.000013 & 0.000032 & 0.000011 & 531 & 510 \\
\hline $\operatorname{lr} 7$ & 0.000020 & 0.000002 & 0.000004 & 0.000006 & 0.000010 & 0.000019 & 0.000007 & 491 & 481 \\
\hline Ir 8 & 0.000027 & 0.000002 & 0.000005 & 0.000008 & 0.000029 & 0.000002 & 0.000007 & 508 & 513 \\
\hline $\operatorname{Ir} 9$ & 0.000024 & 0.000003 & 0.000005 & 0.000007 & 0.000018 & 0.000037 & 0.000012 & 511 & 496 \\
\hline Ol 1 & 0.000162 & 0.000004 & 0.000043 & 0.000020 & 0.000003 & 0.000102 & 0.000049 & 400 & 374 \\
\hline $\mathrm{Ol} 2$ & 0.000223 & 0.000005 & 0.000036 & 0.000020 & 0.000004 & 0.000065 & 0.000031 & 397 & 388 \\
\hline Pu 1 & 0.000080 & 0.000006 & 0.000016 & 0.000014 & n.d. & 0.000003 & 0.000048 & 536 & 514 \\
\hline Pu 2 & 0.000073 & 0.000005 & 0.000014 & 0.000013 & 0.000016 & 0.000003 & 0.000004 & 536 & 520 \\
\hline Pu 3 & 0.000059 & 0.000004 & 0.000012 & 0.000013 & 0.000017 & 0.000006 & 0.000011 & 504 & 498 \\
\hline $\mathrm{Pu} 4$ & 0.000090 & 0.000006 & 0.000018 & 0.000016 & 0.000016 & 0.000004 & 0.000006 & 522 & 505 \\
\hline Al 1 & 0.001843 & 0.000001 & 0.000549 & 0.000033 & n.d. & 0.000219 & 0.000074 & & \\
\hline Al 2 & 0.001790 & 0.000001 & 0.000422 & 0.000023 & n.d. & 0.000294 & 0.000061 & & \\
\hline Al 3 & 0.001974 & 0.000002 & 0.000420 & 0.000033 & n.d. & 0.000289 & 0.000084 & & \\
\hline Al 4 & 0.001921 & 0.000003 & 0.000444 & 0.000023 & n.d. & 0.000559 & 0.000044 & 305 & 290 \\
\hline Al 5 & 0.001579 & 0.000001 & 0.000348 & 0.000028 & n.d. & 0.000169 & 0.000064 & 288 & 294 \\
\hline Al 6 & 0.000969 & 0.000001 & 0.000423 & 0.000027 & n.d. & 0.000124 & 0.000049 & 294 & 280 \\
\hline Al 7 & 0.001109 & 0.000002 & 0.000539 & 0.000026 & n.d. & 0.000160 & 0.000063 & 305 & 284 \\
\hline $\mathrm{Al} 8$ & 0.001092 & 0.000002 & 0.000436 & 0.000022 & n.d. & 0.000183 & 0.000075 & 302 & 282 \\
\hline
\end{tabular}

Table 2. Chemical compositions (dry gas fractions) of light hydrocarbons $\left(\mathrm{C}_{2} \mathrm{H}_{6}, \mathrm{C}_{2} \mathrm{H}_{4}, \mathrm{C}_{3} \mathrm{H}_{8}, \mathrm{C}_{3} \mathrm{H}_{6}, \mathrm{C}_{4} \mathrm{H}_{4} \mathrm{O}, \mathrm{C}_{4} \mathrm{H}_{4} \mathrm{~S}\right.$ and $\left.\mathrm{C}_{6} \mathrm{H}_{6}\right)$ of fumaroles from the Irruputuncu (Ir), Olca (Ol), Putana (Pu) and Alitar (Al) volcanoes. Concentrations of gas compounds are in mmol/mol; n.a.: not analyzed; n.d.: not detected; n.c.: not calculated.

\begin{tabular}{|c|c|c|c|c|c|c|c|c|c|c|c|}
\hline & $\delta^{15} \mathrm{C}-\mathrm{CO}_{2}$ & $R / R_{a}$ & ${ }^{40} \mathrm{Ar} /{ }^{36} \mathrm{Ar}$ & $\mathrm{He} / \mathrm{Ne}$ & $\delta_{\mathrm{D}-\mathrm{H}_{2} \mathrm{O}}$ & ${ }^{818} \mathrm{O}-\mathrm{H}_{2} \mathrm{O}$ & $\mathrm{CO}_{2}{ }^{3} \mathrm{He}$ & $\mathrm{CH}_{4}{ }^{3} \mathrm{He}$ & M (\%) & $\mathrm{S}(\%)$ & $\mathrm{L}(\%)$ \\
\hline Ir 1 & -7.23 & 7.27 & 312 & 170 & -35.1 & 10.4 & $1.88 \times 10^{10}$ & $1.55 \times 10^{5}$ & 8.1 & 22.3 & 69.6 \\
\hline Ir 4 & & & & & -36.8 & 9.3 & & & & & \\
\hline Ir 8 & -6.53 & & & & -44.1 & 7.9 & & & & & \\
\hline $\operatorname{Ir} 9$ & & & & & -43.5 & 6.8 & & & & & \\
\hline Ol 1 & -8.54 & 6.11 & 396 & 164 & -97.5 & -8.4 & $1.72 \times 10^{10}$ & $1.90 \times 10^{6}$ & 8.7 & 26.5 & 64.8 \\
\hline 이 2 & -8.04 & & & & -95.6 & -8.0 & & & & & \\
\hline Pu 1 & & 6.15 & & 103 & & & $2.05 \times 10^{10}$ & $1.11 \times 10^{6}$ & & & \\
\hline Pu 3 & -6.74 & & & & & & & & & & \\
\hline Pu 4 & -7.11 & 7.14 & 339 & 417 & -57.2 & 1.7 & $1.74 \times 10^{10}$ & $4.08 \times 10^{5}$ & 8.7 & 21.8 & 69.5 \\
\hline Al 1 & & & & & -69.6 & -1.2 & & & & & \\
\hline Al 2 & -8.15 & & & & -72.2 & -1.0 & & & & & \\
\hline $\mathrm{Al} 3$ & & & & & -73.4 & -1.6 & & & & & \\
\hline Al 4 & & & & & -70.8 & -1.5 & & & & & \\
\hline Al 5 & -7.75 & 4.80 & 297 & 2136 & -67.8 & -1.6 & $4.04 \times 10^{10}$ & $1.85 \times 10^{\prime}$ & 3.7 & 25.0 & 71.3 \\
\hline Al 6 & -8.01 & & & & & & & & & & \\
\hline
\end{tabular}

Table 3. $\delta^{13} \mathrm{C}-\mathrm{CO}_{2}\left(\%\right.$ V-PDB), R/Ra, $\delta^{18} \mathrm{O}$ and $\delta \mathrm{D}$ (both in \%o V-SMOW) values and ${ }^{40} \mathrm{Ar} /{ }^{36} \mathrm{Ar},{ }^{4} \mathrm{He} /{ }^{20} \mathrm{Ne}, \mathrm{CO}_{2} /{ }^{3} \mathrm{He}$ and $\mathrm{CH}_{4} /{ }^{3} \mathrm{He}$ ratios of fumaroles from the Irruputuncu (Ir), Olca (Ol), Putana (Pu) and Alitar ( $\mathrm{Al}$ ) volcanoes. L, S and M are the limestone, organic sediments and mantle end-members (\%), as defined by Sano and Marty [1995].

systems, which ranged from $-8.54 \%$ o to $-6.53 \%$ V-PDB.

Fumarolic isotopic gas measurements including: noble gases (i.e. ${ }^{3} \mathrm{He} /{ }^{4} \mathrm{He}\left[\mathrm{R} / \mathrm{R}_{\mathrm{A}}\right]$ and $\left.{ }^{40} \mathrm{Ar} /{ }^{36} \mathrm{Ar}\right)$ and $\mathrm{CO} 2\left(\delta^{13} \mathrm{C}-\mathrm{CO}_{2}\right)$; selected gases are given in Table 3. The Irruputuncu fumaroles have the highest ${ }^{3} \mathrm{He} /{ }^{4} \mathrm{He}\left(\mathrm{R} / \mathrm{R}_{\mathrm{A}}\right)$ value $(7.27)$, followed by Putana (Pu1 and Pu4 gases with ${ }^{3} \mathrm{He} /{ }^{4} \mathrm{He}\left[\mathrm{R} / \mathrm{R}_{\mathrm{A}}\right]$ of 6.15 and 7.14, respectively). The Olca $\left(\mathrm{Ol} 1{ }^{3} \mathrm{He} /{ }^{4} \mathrm{He}\left[\mathrm{R} / \mathrm{R}_{\mathrm{A}}\right]\right.$ of 6.11) helium isotopic composition is similar to that of $\mathrm{Pu} 1$, while Alitar is characterized by a significantly lower $R / R_{a}$ value (4.80). The argon isotopic composition $\left({ }^{40} \mathrm{Ar} /{ }^{36} \mathrm{Ar}\right)$ for the Irruputuncu, Olca and Putana gases range between 312 and 396 and contain a moderately radiogenic component, whereas that of Alitar (Al5, 297) is similar to that of air (295.5)
[Ozima and Podosek 2002], and reflects significant influence from air or air-saturated water in this system.

\section{Discussion}

\subsection{Origin of fumarolic fluids}

Volcanic fluids are discharged from volcanic systems along subducting convergent plate boundaries that typically originate from one of the following sources (and may mix to varying extents amongst these sources): 1) mantle or mantle-wedge magmatic degassing; 2) fluid-rock interactions at the various temperatures along the arc; and 3) air or air-saturated water (dissolved in permeating meteoric 

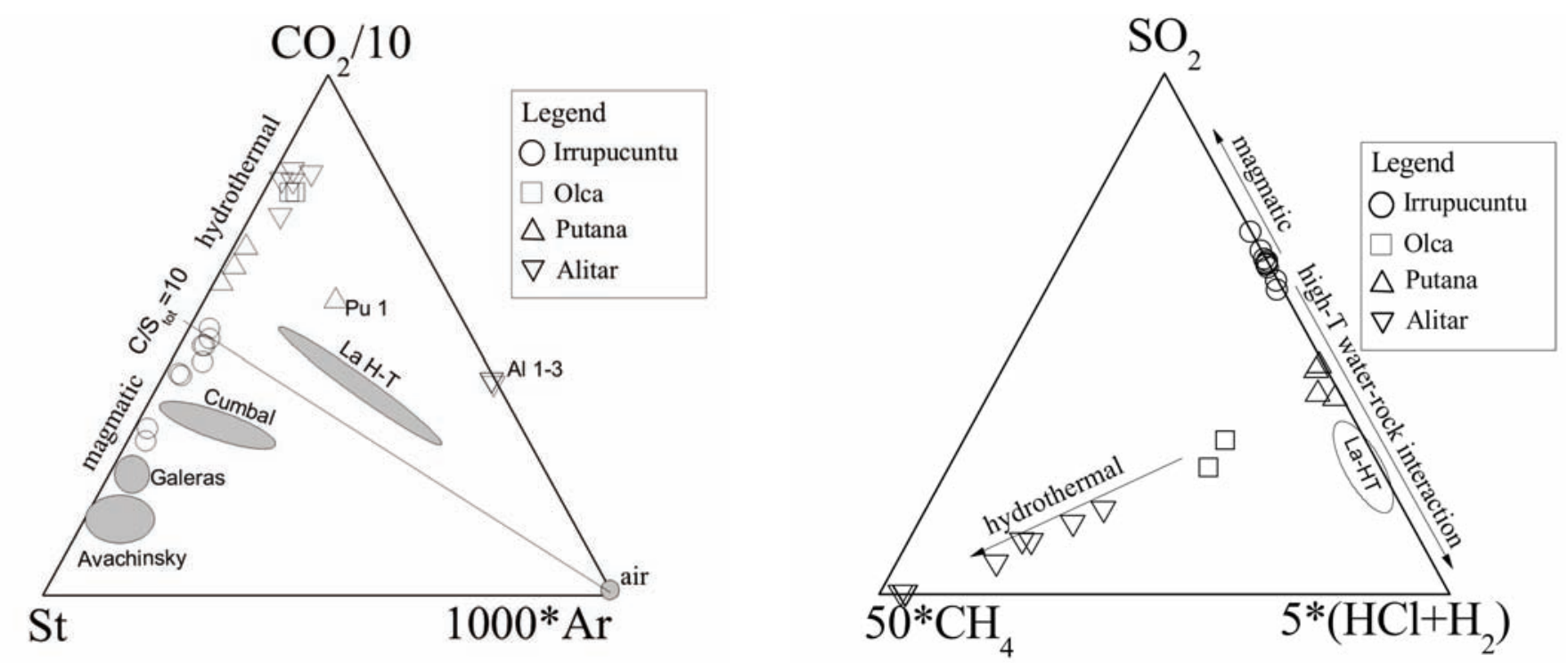

Figure 6 (left). Ar- $\mathrm{CO}_{2}-\left(\mathrm{SO}_{2}+\mathrm{H}_{2} \mathrm{~S}\right)$ ternary diagram for the Irruputuncu (open circles), Olca (open squares), Putana (open triangles up) and Alitar (open triangles down) fumarole gases. For comparison, the compositions of Lascar (La-HT) [Tassi et al. 2009], Avachinski (Kamchatka) [Taran et al. 1997], Galeras (Colombia) [Fischer et al. 1997] and Cumbal (Colombia) [Lewicki et al. 2000] gases are also shown.

Figure 7 (right). $\left(\mathrm{HCl}+\mathrm{H}_{2}\right)-\mathrm{SO}_{2}-\mathrm{CH}_{4}$ ternary diagram. Symbols as in legend to Figure 6. For comparison, the composition of the Lascar gases (La-HT) [Tassi et al. 2009] is also shown.

water or degassed from water in subducting slab sediments) [Poreda et al 1988, Poorter et al. 1991, Giggenbach 1992a, Giggenbach 1996, Snyder et al. 2001, Snyder et al. 2003].

We determined the relative contributions of each of these sources for this region in the CAVZ. We used the Ar$\mathrm{CO}_{2}-\left(\mathrm{SO}_{2}+\mathrm{H}_{2} \mathrm{~S}\right)$ ternary diagram (Figure 6) to demonstrate that the fumarolic gas composition is accounted for by a mixture between hydrothermal and magmatic sources, with minimal atmospheric (air or air-saturated water) contributions. The Irruputuncu gases are characterized by $\mathrm{C} / \mathrm{St}$ ratios $<10$ (where $\mathrm{St}$ is the sum of $\mathrm{SO}_{2}+\mathrm{H}_{2} \mathrm{~S}$ ), which is typical of magmatic gases from andesitic volcanoes [Symonds et al. 1994] and is similar to those of other active volcanoes located along subducting convergent plate boundaries, i.e. Avachinsky (Kamchatka), Galeras Cumbal and Galeras (Colombia) [Fischer et al. 1997, Taran et al. 1997, Lewicki et al. 2000]. Interestingly, this low C/St ratio is less than those observed at medium-high-temperature (between $150{ }^{\circ} \mathrm{C}$ and $385^{\circ} \mathrm{C}$ ) fumaroles from other CAVZ systems, including Lascar (La-HT) [Tassi et al. 2009], a frequently eruptive stratovolcano located few dozen kilometers south of Putana [Gardeweg and Medina 1994, Aguilera et al. 2003, Aguilera et al. 2006, Clavero et al. 2006]. Compared to Irruputuncu, the Olca and Alitar fumaroles show significantly higher $\mathrm{C} / \mathrm{St}$ ratios (ranging from 33 to 65 ), that we suggest is related to a relatively high contribution from hydrothermal fluids, while the gases at Putana have intermediate C/St ratios (between 15 and 27). Several fumaroles included in this study have anonymously high $\mathrm{Ar}$ contributions than described above (and cannot be explained by a simple two-component magmatic/hydrothermal mixture) including: 1) the Pu1 fumarole, which we attribute to air contamination because of the concomitant increase in $\mathrm{O}_{2}$ concentrations $(0.41 \mathrm{mmol} / \mathrm{mol}$; Table 1$)$; and 2) the three bubbling gas pools from Alitar volcano, which were also characterized by relatively low $\mathrm{H}_{2} \mathrm{~S}$ concentrations (low St), which we attribute to liquid-gas interactions at shallow depths and increased interactions with shallow air-rich groundwater. These types of secondary processes might, at least partially, explain the high $\mathrm{C} / \mathrm{St}$ ratios of the Olca and Alitar fumaroles, as the solubility in water of the sulfur gas compounds is significantly higher than that of $\mathrm{CO}_{2}$. To better define this system, we constructed the $\left(\mathrm{HCl}+\mathrm{H}_{2}\right)-\mathrm{SO}_{2}-\mathrm{CH}_{4}$ ternary diagram (Figure 7), assuming: (i) gas-water-rock interactions produce $\mathrm{H}_{2}$ and $\mathrm{HCl}$ at relatively high temperatures [Martini 1993]; (ii) $\mathrm{SO}_{2}$ is a direct proxy for magmatic contributions [Giggenbach 1980, 1996]; and (iii) $\mathrm{CH}_{4}$ in volcanic environments originates from thermal decomposition of organic material and/or abiogenic processes (i.e. Sabatier reaction involving $\mathrm{CO}_{2}$ and $\mathrm{H}_{2}$ that occurs under hydrothermal conditions) [Schoell 1988, Whiticar and Suess 1990, Giggenbach 1997, Darling 1998, Horita and Berndt 1999, Sherwood-Lollar et al. 2002, Fiebig et al. 2004, Fiebig et al. 2007]. Our findings here are in agreement with those indicated by the $\mathrm{C} / \mathrm{St}$ ratios (Figure 6), and they suggest that the fumarolic gases from these volcanoes can be defined according to only magmatic and hydrothermal contributions. We find that the Irruputuncu fumarolic gases, and to a lesser extent those of Putana, have a distinct magmatic signature that is more prominent than the highly active Lascar (La-HT) fumaroles. Conversely, the Alitar and Olca gases show a significant enrichment in $\mathrm{CH}_{4}$, and are thus strongly affected by fluid contributions from a hydrothermal source (Figure 7). 
By evaluating the stable isotopic compositions $\left(\delta^{18} \mathrm{O}\right.$ and $\delta \mathrm{D}$ ) of the steam condensates (Figure 8), we show that all four of the Chilean volcanoes included in this study, and including Lascar, plot along a binary mixing line between the northern Chile local meteoric water line [Aravena 1995, Chaffaut et al. 1998, Aravena et al. 1999] and the suggested "andesitic water magmatic" field [Taran et al. 1989, Giggenbach 1992b]. In relative terms, the trend shown in Figure 8 supports our findings for the magmatic, hydrothermal, and air-saturated water contributions shown in Figures 6 and 7. We find that an andesite water magmatic end-member dominates the Irruputuncu gases (Figure 8), which agrees with our findings for the gas composition (Figures 6 and 7) and the high helium isotopic composition $\left(\mathrm{R} / \mathrm{R}_{\mathrm{A}}, 7.27\right)$ at Irruputuncu (Table 3). Helium isotopic compositions between 7-9 $\mathrm{Ra}$ indicate the presence of a strong contribution from upper mantle or mantle-wedge fluids without the significant addition of crustal fluids [Craig and Lupton 1976, Javoy et al. 1982, Poreda et al. 1988, Rollinson 1993]. Conversely, the $\delta^{18} \mathrm{O}$ and $\delta \mathrm{D}$ isotopic signatures of the Putana, Alitar and Olca fumaroles can be regarded as derived by mixing processes between magmatic fluids and meteoric water in comparable amounts (Figure 8).

Aside from water vapor, $\mathrm{CO}_{2}$ is the most prominent gas present in all of the samples included in the present study. We determined the source of $\mathrm{CO}_{2}$ using carbon isotopic composition and the relative proportion of $\mathrm{CO}_{2}$ to ${ }^{3} \mathrm{He}$, a conservative, primordial mantle-gas tracer. All of the samples included in this study have $\delta^{13} \mathrm{C}-\mathrm{CO}_{2}$ values in the range of mid-ocean ridge basalt (MORB) gases $(-9 \%$ to -4\%o V-PDB) [Marty and Jambon 1987, Javoy and Pineau 1991, Sano and Marty 1995], and do not vary systematically in the volcanoes included in the present study. The $\mathrm{CO}_{2} /{ }^{3} \mathrm{He}$ ratio is a sensitive tracer that can distinguish the removal ("scrubbing") and/or addition of $\mathrm{CO}_{2}$ in fumarole gases, and specifically the addition of $\mathrm{CO}_{2}$ to magmatic sources [e.g. Tedesco et al. 2010]. We find that the $\mathrm{CO}_{2} /{ }^{3} \mathrm{He}$ ratios from all the investigated volcanic systems range between $1.73 \times 10^{10}$ and $6.05 \times 10^{10}$. This range is consistent with typical of fumarole gases from an arc setting and are approximately one order of magnitude higher than those of MORB and Ocean Island basalt gases [Des Marais and Moore 1984, Marty and Jambon 1987, Marty and Tostikhin 1998], probably due to the addition of $\mathrm{CO}_{2}$ from carbonate-rich sediments released from the subducting slab [Giggenbach and Poreda 1993, Sano and Williams 1996, Patino et al. 2000, Snyder et al. 2001].

In subduction zones, $\mathrm{CO}_{2}$ primarily originates from one of three sources: 1) sedimentary organic (S);2) limestone (L); and 3) MORB (a representative for upper mantle gas) (M), with minimal crustal-derived contributions [e.g. Hilton et al. 2002]. We evaluated the relative contributions of each source in the CAVZ using the following equations [Sano and Marty 1995]:

$$
\mathrm{M}+\mathrm{S}+\mathrm{L}=1
$$

$\left(\delta^{13} \mathrm{C}-\mathrm{CO}_{2}\right)_{o b s}=$

$\left(\delta^{13} \mathrm{C}-\mathrm{CO}_{2}\right)_{\text {MORB }} \mathrm{M}+\left(\delta^{13} \mathrm{C}^{-\mathrm{CO}_{2}}\right)_{\text {Lim }} \mathrm{L}+\left(\delta^{13} \mathrm{C}-\mathrm{CO}_{2}\right)_{\text {Sed }} \mathrm{S}$

$1 /\left({ }^{12} \mathrm{C} /{ }^{3} \mathrm{He}\right)_{o b s}=$

$\mathrm{M} /\left({ }^{12} \mathrm{C} /{ }^{3} \mathrm{He}\right)_{\text {MORB }}+\mathrm{L} /\left({ }^{12} \mathrm{C} /{ }^{3} \mathrm{He}\right)_{\text {Lim }}+\mathrm{S} /\left({ }^{12} \mathrm{C} /{ }^{3} \mathrm{He}\right)_{\text {Sed }}$

where subscripts obs, MORB, Lim and Sed refer to the sample, MORB (a proxy for upper mantle contributions), limestone and sediment, respectively. We assume that the end members have the following compositions:

$$
\begin{gathered}
\left(\delta^{13} \mathrm{C}_{-} \mathrm{CO}_{2}\right)_{\text {MORB }}=-6.5 \%,\left(\delta^{13} \mathrm{C}-\mathrm{CO}_{2}\right)_{\text {Lim }}= \\
0 \%,\left(\delta^{13} \mathrm{C}^{-\mathrm{CO}_{2}}\right)_{\text {Sed }}=-30 \%,\left({ }^{12} \mathrm{C} /{ }^{3} \mathrm{He}\right)_{\text {MORB }}= \\
1.5 \times 10^{9},\left({ }^{12} \mathrm{C} /{ }^{3} \mathrm{He}\right)_{\text {Lim }}=1 \times 10^{13},\left({ }^{12} \mathrm{C} /{ }^{3} \mathrm{He}\right)_{\text {Sed }}=1 \times 10^{13} .
\end{gathered}
$$

The results for each contribution are presented in Table 3. We find that the calculated relative amounts for each of the three potential carbon sources (i.e. M, S and L) result in a maximum contribution of $8.7 \%$ magmatic (M) $\mathrm{CO}_{2}$ with a ratio of limestone/ sedimentary carbon $(\mathrm{L} / \mathrm{S}) \sim 3$ at Irruputuncu, Olca and Putana. These data are consistent with previous findings for Lascar volcano [Tassi et al. 2009], as well as for other arc volcanoes in Salvador and Costa Rica [Shaw et al. 2003, de Leeuw et al. 2007]. Alitar gas contains

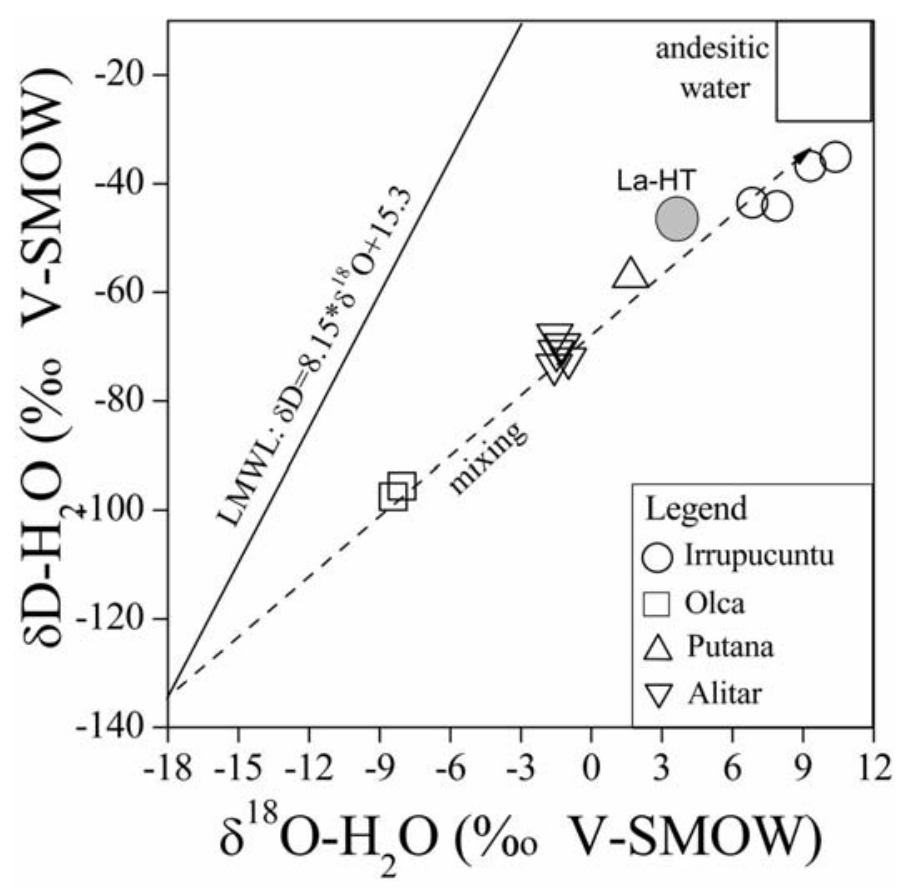

Figure 8. $\delta^{2} \mathrm{H}$ versus $\delta^{18} \mathrm{O}$ binary diagram. The "andesitic water" field [Taran et al. 1989, Giggenbach 1992b], and the local meteoric water line (LMWL: $\delta^{2} \mathrm{H}=8.15 \delta^{18} \mathrm{O}+15.3$ ) [Chaffaut et al. 1998] are also shown. Symbols as in legend to Figure 6. For comparison, the isotopic composition of Lascar gases (La-HT) [Tassi et al. 2009] is also shown. 
the lowest magmatic contribution (M: $3.7 \%$ ), which is more consistent with geothermal systems in northern Chile than these CAVZ volcanic systems [Tassi et al. 2010a]. These results suggest that the majority $(>90 \%)$ of $\mathrm{CO}_{2}$ at these volcanoes in the CAVZ is derived from nonmagmatic (non-mantle) sources. Instead, the $\mathrm{CO}_{2}$ is primarily derived from the devolatilization of subducting carbonates and to a lesser extent from thermogenic interactions with carbon in rocks and sediments, which will be discussed further below.

To further constrain the origins of the gases from potential thermogenic interactions of hot fluids with rocks/sediments and slab devolatilization, we evaluated the relative abundances of $\mathrm{N}_{2}, \mathrm{Ar}$ and $\mathrm{He}$ (Figure 9). The $\mathrm{N}_{2} / \mathrm{Ar}$ ratio can be used to distinguish the relative contributions to a gas mixture from air, air-saturated fluids, thermogenic interactions with subducting and surficial rocks/sediments, and mantle gases [e.g. Snyder et al. 2001, 2003]. The gas composition of the volcanoes in the present study is marked by high $\mathrm{N}_{2} / \mathrm{Ar}$ ratios (up to 1,509 ) relative to air $(82)$. These high $\mathrm{N}_{2}$ / Ar ratios are typical of subduction-zone andesitic gas emissions [Matsuo et al. 1978, Giggenbach 1992b], where $\mathrm{N}_{2}$ is extracted from the subducting slab and slab sediments as the temperatures increase during the subduction process [Snyder et al. 2003]. Note that in the present study, the $\mathrm{N}_{2} / \mathrm{Ar}$ ratio identifies two distinct trends (Irruputuncu and Putana vs. Olca and Alitar) for the source of the thermogenic $\mathrm{N}_{2}$, including: 1) subducting-slab-generated $\mathrm{N}_{2}$; and 2) "crustal-like" $\mathrm{N}_{2}$ that suggests the addition of $\mathrm{N}_{2}$ from crustal (near surface) sources, and most likely from the interactions of heated groundwater with crustal volcanic sequences closer to the surface. The addition of crustal ${ }^{4} \mathrm{He}$ is supported by the decrease in $\mathrm{R} / \mathrm{R}_{\text {air }}$ for Olca and Alitar (6.11 and 4.80), as compared to

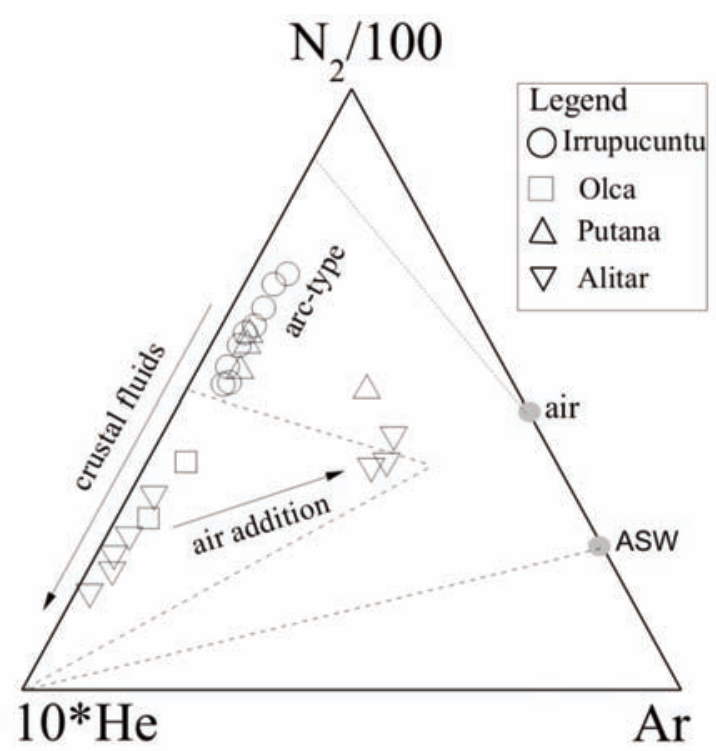

Figure 9. Ar- $\mathrm{N}_{2}-\mathrm{He}$ ternary diagram. ASW, air-saturated water. Symbols as in legend to Figure 6.
Irruputuncu (7.27) and Putana (6.15-7.14) (Table 3).

The Irruputuncu and Putana gases are similar to those of arc-type andesitic volcanism and they contain relatively low He and Ar, while the Olca and Alitar fumaroles show significant He enrichment (specifically ${ }^{4} \mathrm{He}$ enrichment, as inferred from the lower $\mathrm{R} / \mathrm{R}_{\mathrm{a}}$; Table 3), with minimal addition of Ar in most samples. Note that the Alitar bubbling pools and the one Putana sample (Pu1) suspected of mixing with air, as discussed above, each plot along a mixing line between other gases from the respective volcano and the air composition (Figure 9). Interestingly, these samples do not appear to mix with air-saturated water, indicating minimal interactions with noble gases dissolved in groundwater for these samples.

The origins of light hydrocarbons are commonly investigated on the basis of the relative abundance of the $\mathrm{C}_{1}$ $\mathrm{C}_{3}$ alkanes in fumarolic gases [Oremland et al. 1987, Whiticar and Suess 1990, Kiyosu et al. 1992, Darling 1998]. Gases produced by decay of organic matter at temperatures $>150{ }^{\circ} \mathrm{C}$ are characterized by $\mathrm{CH}_{4} /\left(\mathrm{C}_{2} \mathrm{H}_{6}+\mathrm{C}_{3} \mathrm{H}_{8}\right)$ ratios $<100$, whereas higher ratios are expected when processes related to bacteria activity at low temperatures are responsible for hydrocarbon production. Based on these assumption, the light hydrocarbons present at Irruputuncu, Putana, Olca and Alitar would be characterized as originating from a bacteriarelated source, because the $\mathrm{CH}_{4} /\left(\mathrm{C}_{2} \mathrm{H}_{6}+\mathrm{C}_{3} \mathrm{H}_{8}\right)$ ratios range between 158 and 603 . However, we suggest that a bacteriarelated origin is not likely. We do not anticipate that hydrocarbon production can be attributed to bacterial activity in fluids so strongly related to magmatic degassing, and specifically those with discharge temperatures higher than the temperatures at which bacteria are anticipated to survive $\left(\sim 120^{\circ} \mathrm{C}\right)$. Instead, we prefer an alternative process in which the high temperatures and highly oxidizing conditions created by the presence of water-rich, high-temperature, magmatic-related fluids results in a thermal cracking process that preferentially destroys long-chain hydrocarbons, altering the $\mathrm{CH}_{4} /\left(\mathrm{C}_{2} \mathrm{H}_{6}+\mathrm{C}_{3} \mathrm{H}_{8}\right)$ ratio. This hypothesis can explain: (i) the lack of $\mathrm{C}_{3+}$ species, with the possible exception of benzene, furane and thiophene, which are stable at relatively high temperatures [Montegrossi et al. 2003, Capaccioni et al. 2005, Tassi et al. 2010b]; (ii) the $\mathrm{CH}_{4}$ "excess" with respect to the $\mathrm{C}_{2} \mathrm{H}_{6}$ and $\mathrm{C}_{3} \mathrm{H}_{8}$ concentrations; and (iii) the relatively low $\mathrm{CH}_{4} /{ }^{3} \mathrm{He}$ ratios $\left(1.55 \times 10^{5}\right.$ to $\left.1.85 \times 10^{7}\right)$ that are lower than those observed for gases produced by thermogenic processes in an organic-rich hydrothermal environment (up to $1 \times 10^{12}$ ) [Poreda et al. 1988]. Relatively high $\mathrm{CH}_{4}$ concentrations in hydrothermal fluids from submarine ultramafic-hosted systems [Charlou et al. 2002, Proskurowski et al. 2008, Konn et al. 2009] and in springs discharging from ophiolites [Abrajano et al. 1990] were ascribed to $\mathrm{CH}_{4}$ production through catalytic hydrogenation of carbon oxygenated species, the so-called Fischer-Tropsch-type reaction. Fiebig 
et al. [2007, 2009] suggested that the occurrence of a FischerTropsch-type reaction is responsible of excess methane in continental hydrothermal emissions. Isotopic data $\left(\delta^{13} \mathrm{C}\right.$ and $\delta \mathrm{D})$ of $\mathrm{CH}_{4}$ and light alkanes, which were not available for the present study, could provide useful information about the origin of these species [Sherwood Lollar et al. 2006, Fu et al. 2007, Taran et al. 2007, McCollom et al. 2010, Taran et al. 2010]. However, on the basis of the reported chemical evidence, we can argue that the concentrations of $\mathrm{CH}_{4}$ are independent of light alkanes, with the former being regulated by the $\mathrm{CO}_{2}-\mathrm{CH}_{4}$ chemical equilibrium instead of the decay of organic matter.

\subsection{Geothermometry}

We can estimate the thermodynamic conditions of a deep reservoir source for fumarolic fluids by assuming equilibrium conditions for reactions involving specific gas compounds. The $\mathrm{H}_{2} / \mathrm{H}_{2} \mathrm{O}$ log-ratio $\left(\mathrm{R}_{\mathrm{H}}\right)$ is considered to be the most suitable parameter for describing the redox state of most natural fluids [Giggenbach 1987]. In hydrothermal fluids, redox conditions are regulated by the $\mathrm{FeO}-\mathrm{FeO}_{1.5}$ pair in rocks, which produces a $\mathrm{R}_{\mathrm{H}}$ of -2.8 almost independent of temperature. Alternatively $\mathrm{H}_{2}$ concentrations and the redox potential in gases related to magmatic degassing are controlled by the $\mathrm{SO}_{2}-\mathrm{H}_{2} \mathrm{~S}$ gas buffer [Giggenbach 1997, and references therein]. Equilibrium constraints in the $\mathrm{H}_{2} \mathrm{O}-\mathrm{CO}_{2}-\mathrm{CO}-\mathrm{H}_{2}$ system are provided by the following pressure-independent reaction:

$$
\mathrm{CO}_{2}+\mathrm{H}_{2} \longleftrightarrow \mathrm{CO}+\mathrm{H}_{2} \mathrm{O}
$$

Reaction (4) is strongly controlled by a temperaturedependent equilibrium constant, according to [Giggenbach 1996]:

$$
\log \left(\mathrm{CO} / \mathrm{CO}_{2}\right)-\left(\mathrm{H}_{2} / \mathrm{H}_{2} \mathrm{O}\right)=2.49-2248 / \mathrm{T}(\mathrm{K})
$$

In the $\log \left(\mathrm{H}_{2} / \mathrm{H}_{2} \mathrm{O}\right)$ versus $\log \left(\mathrm{CO} / \mathrm{CO}_{2}\right)$ diagram (Figure 10), the Irruputuncu and Putana gases correspond to equilibrium temperatures ranging between $420{ }^{\circ} \mathrm{C}$ and 580 ${ }^{\circ} \mathrm{C}$, whereas the Olca and Alitar fumaroles appear to equilibrate at $340{ }^{\circ} \mathrm{C}$ to $410^{\circ} \mathrm{C}$. It is worth noting that in these systems, the $\mathrm{SO}_{2}-\mathrm{H}_{2} \mathrm{~S}$ pair is the dominant redox buffer, which is consistent with the presence of significant concentrations of these two gas compounds in the fumarolic gases (Table 1). The $\mathrm{H}_{2} \mathrm{O}-\mathrm{CO}-\mathrm{CO}_{2}-\mathrm{H}_{2}$ geothermometer indicates ureliable low temperatures $\left(<100{ }_{2} \mathrm{C}\right)$ for the Alitar bubbling gases that are significanlty affected by $\mathrm{H}_{2} \mathrm{O}$ condensation and $\mathrm{CO}$ dissolution within the bubbling pools. The gas species in the $\mathrm{H}_{2} \mathrm{O}-\mathrm{CO}_{2}-\mathrm{CH}_{4}-\mathrm{H}_{2}$ system are controlled by the Sabatier reaction, as follows:

$$
\mathrm{CH}_{4}+2 \mathrm{H}_{2} \mathrm{O} \longleftrightarrow \mathrm{CO}_{2}+4 \mathrm{H}_{2}
$$

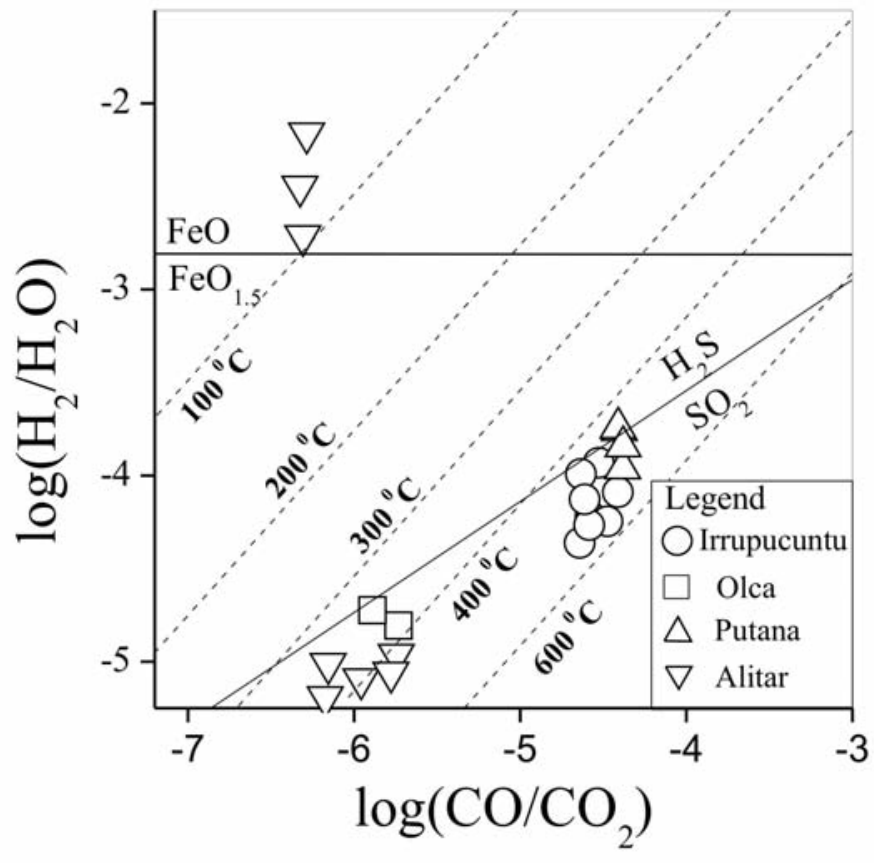

Figure 10. $\log \left(\mathrm{H}_{2} / \mathrm{H}_{2} \mathrm{O}\right)$ versus $\log \left(\mathrm{CO} / \mathrm{CO}_{2}\right)$ diagram. Solid lines refer to equilibria controlled by the $\mathrm{FeO}-\mathrm{FeO}_{1.5}$ and the $\mathrm{SO}_{2}-\mathrm{H}_{2} \mathrm{~S}$ redox pairs. Dashed lines are the calculated isotherms for the simultaneous equilibrium of the $\mathrm{H}_{2}-\mathrm{H}_{2} \mathrm{O}$ and the CO- $\mathrm{CO}_{2}$ geothermometers. Symbols as in legend to Figure 6 .

Assuming that $\log \mathrm{fH}_{2} \mathrm{O}=4.9-1820 / \mathrm{T}$ [Giggenbach 1987], the temperature dependence of the equilibrium constant of reaction (6) can be expressed by the following equation:

$$
\log \left(\mathrm{CH}_{4} / \mathrm{CO}_{2}\right)-4 \log \left(\mathrm{H}_{2} / \mathrm{H}_{2} \mathrm{O}\right)=5181 / \mathrm{T}(\mathrm{K})
$$

According to Equations (6) and (7), the thermodynamic conditions of the equilibria among the carbon gas species (i.e. $\mathrm{CO}_{2}, \mathrm{CH}_{4}$ and $\mathrm{CO}$ ) can be shown by the $\log \left(\mathrm{CH}_{4} / \mathrm{CO}_{2}\right)$ versus $\log \left(\mathrm{CO} / \mathrm{CO}_{2}\right)$ diagram [Giggenbach 1987], where compositions that have equilibria controlled by the $\mathrm{FeO}-\mathrm{FeO}_{1.5}$ and $\mathrm{SO}_{2}-\mathrm{H}_{2} \mathrm{~S}$ redox pairs are also reported (Figure 11). The $\mathrm{CO}_{2}-\mathrm{CH}_{4}-\mathrm{CO}$ equilibrium temperatures of the Irruputuncu and Putana gases are $320^{\circ} \mathrm{C}$ to $390^{\circ} \mathrm{C}$, whereas those of the Olca and Alitar fumaroles are $<180{ }^{\circ} \mathrm{C}$. The decoupling between the fluid temperatures, calculated by using the $\mathrm{H}_{2} \mathrm{O}-\mathrm{CO}_{2}-\mathrm{CO}-\mathrm{H}_{2}$ and $\mathrm{CO}_{2}-\mathrm{CH}_{4}-\mathrm{CO}$ geothermometers, is probably caused by the relatively low kinetics of reaction (6) with respect to that of reaction (4). Indeed, the gas samples in Figure 11 plot far from both the $\mathrm{FeO}-\mathrm{FeO}_{1.5}$ and $\mathrm{SO}_{2}-\mathrm{H}_{2} \mathrm{~S}$ equilibrium lines. The $\mathrm{CO}_{2}-\mathrm{CH}_{4}$ pair is quenched at relatively high temperatures (between $370{ }^{\circ} \mathrm{C}$ and $650{ }^{\circ} \mathrm{C}$, considering the $\mathrm{FeO}-\mathrm{FeO}_{1.5}$ redox buffer), whereas $\mathrm{H}_{2}$ and $\mathrm{CO}$ tend to reequilibrate at lower temperatures as fumarolic fluids rise toward the surface.

Because of non-equilibrium (quenching) conditions, we additionally investigate the thermodynamic conditions that characterize deep fluid source regions on the basis of the 


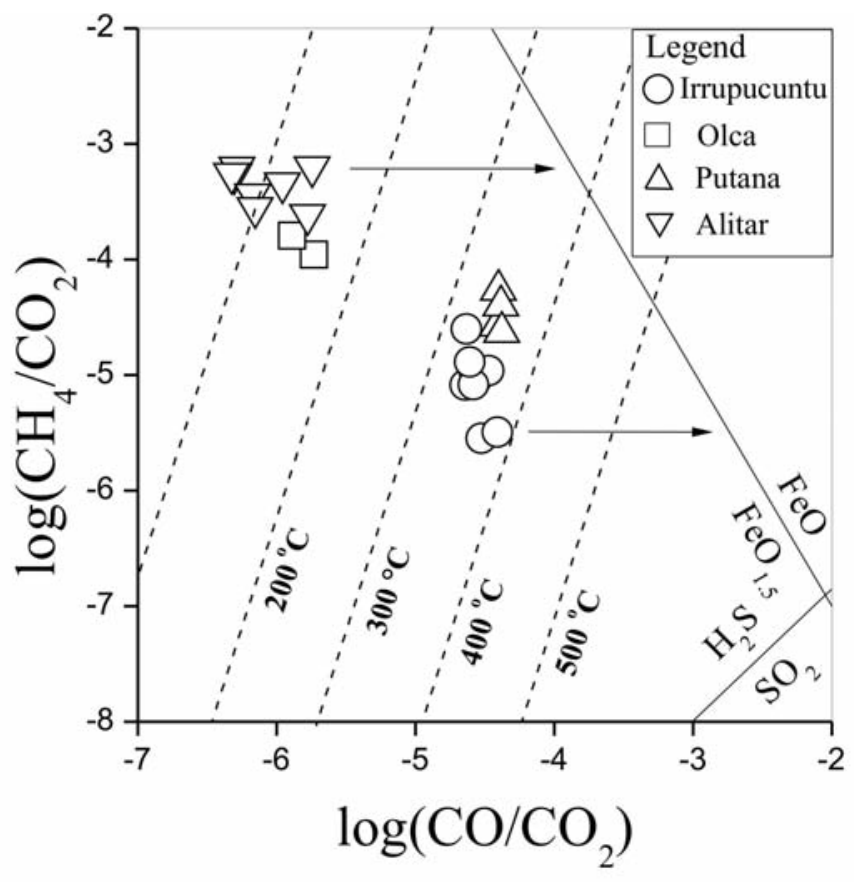

Figure 11. $\log \left(\mathrm{CH}_{4} / \mathrm{CO}_{2}\right)$ versus $\log \left(\mathrm{CO} / \mathrm{CO}_{2}\right)$ diagram. Solid lines refer to equilibria controlled by the $\mathrm{FeO}-\mathrm{FeO}_{1.5}$ and the $\mathrm{SO}_{2}-\mathrm{H}_{2} \mathrm{~S}$ redox pairs. Dashed lines are the calculated isotherms for the simultaneous equilibrium of the $\mathrm{H}_{2}-\mathrm{H}_{2} \mathrm{O}$ and the CO- $\mathrm{CO}_{2}$ geothermometers. Symbols as in legend to Figure 6 .

chemical features of the $\mathrm{C}_{2}$ and $\mathrm{C}_{3}$ alkenes-alkanes pairs [Capaccioni and Mangani 2001, Taran and Giggenbach 2003, Tassi et al. 2005a, Tassi et al. 2005b]. follows:

De-hydrogenation of $\mathrm{C}_{2} \mathrm{H}_{6}$ to produce $\mathrm{C}_{2} \mathrm{H}_{4}$ is, as

$$
\mathrm{C}_{2} \mathrm{H}_{6} \longleftrightarrow \mathrm{C}_{2} \mathrm{H}_{4}+\mathrm{H}_{2}
$$

The temperature dependence of the equilibrium constant for reaction (8) is [Capaccioni et al. 2004]:

$$
7.43-8,809 / \mathrm{T}(\mathrm{K})=\log \left(\mathrm{C}_{2} \mathrm{H}_{4} / \mathrm{C}_{2} \mathrm{H}_{6}\right)+\log \mathrm{H}_{2}
$$
follows:

De-hydrogenation of $\mathrm{C}_{3} \mathrm{H}_{8}$ to produce $\mathrm{C}_{3} \mathrm{H}_{6}$ is as

$$
\mathrm{C}_{3} \mathrm{H}_{8} \longleftrightarrow \mathrm{C}_{3} \mathrm{H}_{6}+\mathrm{H}_{2}
$$

The temperature dependence of the equilibrium constant for reaction (10) is [Capaccioni et al. 2004]:

$$
7.15-6,600 / \mathrm{T}(\mathrm{K})=\log \left(\mathrm{C}_{3} \mathrm{H}_{6} / \mathrm{C}_{3} \mathrm{H}_{8}\right)+\log \mathrm{H}_{2}
$$

We calculated equilibrium temperatures from Equations (9) and (11) $\left(\mathrm{T}_{\mathrm{C} 2-\mathrm{C} 2}\right.$ and $\mathrm{T}_{\mathrm{C} 3-\mathrm{C} 3}$, respectively) using the $\mathrm{H}_{2}$ concentrations measured. These calculations were not performed for the Alitar bubbling gases, as the $\mathrm{H}_{2}$ concentrations of these samples are strongly affected by liquid-gas interactions at low temperatures (Figure 10). As shown in Table 2, both of the sets of calculated temperatures indicate that the Irruputuncu and Putana gases equilibrate at $478{ }^{\circ} \mathrm{C}$ to $536{ }^{\circ} \mathrm{C}$, whereas those of the Olca and Alitar gases range from $280{ }^{\circ} \mathrm{C}$ to $400{ }^{\circ} \mathrm{C}$, in agreement with the temperature estimations in the $\mathrm{H}_{2} \mathrm{O}-\mathrm{CO}_{2}-\mathrm{CO}-\mathrm{H}_{2}$ system.

\section{Concluding remarks}

The chemical and isotopic $\left(\mathrm{R} / \mathrm{R}_{\mathrm{a}}, \delta^{18} \mathrm{O}-\mathrm{H}_{2} \mathrm{O}, \delta \mathrm{D}-\mathrm{H}_{2} \mathrm{O}\right.$ and $\delta^{13} \mathrm{C}_{-} \mathrm{CO}_{2}$ ) compositions of gases emitted from the Irruputuncu, Putana, Olca and Alitar volcanoes suggest a mixture between magmatic, hydrothermal and atmosphericrelated fluids, as typically occurs in volcanic systems along convergent/subduction plate boundaries. We suggest that magmatic degassing is the dominating fluid source at Irruputuncu and Putana. The Olca and Alitar gases show high-temperature gas compounds (i.e. presence of $\mathrm{SO}_{2}$ ), and significant contributions from hydrothermal components. The $\mathrm{R} / \mathrm{R}_{\mathrm{a}}$ and the $\mathrm{CO}_{2} /{ }^{3} \mathrm{He}$ ratios of the four investigated volcanic systems are consistent with those for the CAVZ and subduction arc systems worldwide. All four systems emit gases with magmatic carbon components below $10 \%$, while the lower proportion of magmatic carbon in Alitar fluids supports our assertions that fluids discharging at this volcano are fed by a well-developed hydrothermal system. Gas geothermometry in the $\mathrm{H}_{2} \mathrm{O}-\mathrm{CO}_{2}-\mathrm{CO}-\mathrm{H}_{2}, \mathrm{CO}_{2}-\mathrm{CH}_{4}$ and $\mathrm{C}_{2}-\mathrm{C}_{3}$ alkenes-alkanes systems, consistently indicates that the Irruputuncu and Putana fluids are quenched at relatively high temperatures $\left(>500{ }^{\circ} \mathrm{C}\right)$, which suggests hot magmaticrelated gases rapidly interact with cooler hydrothermal fluids as they ascend to the surface. However, only a very small amount of interaction between magmatic fluids and shallow aquifers is feasible based on our data. Conversely, significantly lower equilibrium temperatures $\left(<400{ }^{\circ} \mathrm{C}\right)$ of the fluids from the Olca and Alitar volcanoes are likely to be attained within hydrothermal systems overlying the magmatic source.

On the whole, the Irruputuncu, Putana, Olca and Alitar volcanoes are variably affected by mixing between deepseated (magmatic) and shallower (hydrothermal) sources, both which suggest that each of these edifices remain active. Consequently, although these volcanoes are located in remote areas of northern Chile, we suggest that periodic (e.g. on a yearly basis) sampling of the fumarolic gas discharges is required to monitor the evolution of the most relevant geochemical and isotopic parameters. Periodic monitoring will allow researchers to develop an accurate geological hazard assessment for these volcanoes and the gain an understanding of the volcanic hazard potential that can result from their activity.

Acknowledgements. This study was partially financed by Dirección General de Investigación y Postgrado (UCN-Chile) and by D-21050592 CONICYT grant (Government of Chile). A. Rizzo and S. Inguaggiato are warmly thanked for the comments and suggestions they provided on an earlier version of the manuscript. The authors wish to express their gratitude to Jaime Llanos (Inorganic Chemical Laboratory-UCN-Chile) for facilities in sample preparation, and to José Luis Mercado and Benigno Godoy (UCN-Chile) for their help during the sampling campaigns. 


\section{References}

Abrajano, T.A., N.C. Sturchio, B.M. Kennedy, G.L. Lyon, K. Muehlenbachs and J.K. Bohlke (1990). Geochemistry of reduced gas related to serpentinization of the Zambales ophiolite, Philippines, Appl. Geochem., 5, 625-630.

Aguilera, F., C. Martínez, F. Tassi, J. Viramonte, E. Medina and H. Vargas (2003). Actividad del Volcán Lascar en el periodo 2000-2002, 10th Chilean Geological Congress, Concepción, Chile.

Aguilera, F., J. Viramonte, E. Medina, K. Guzmán, R. Becchio, H. Delgado and M. Arnosio (2006). Eruptive activity from Lascar volcano (2003-2005), 11th Chilean Geological Congress, Antofagasta, Chile, 397-400.

Aguilera, F. (2008). Origen y naturaleza de los fluidos en los sistemas volcanicos geotermales y termalismo de baja entalpia de la zona volcanica central (ZVC) entre los $17^{\circ} 43^{\prime} \mathrm{S}$ Y $25^{\circ} 10^{\prime} \mathrm{S}$, PhD thesis, Universidad Catolica del Norte, Antofagasta, Chile, 393 pp.

Aravena, R. (1995). Isotope hydrology and geochemistry of northern Chile groundwaters, Bull. Inst. Fr. Études Andines, 24, 497-503.

Aravena, R., O. Suzuki, H. Peña, A. Pollastri, H. Fuenzalida and A. Grilli (1999). Isotopic composition and origin of the precipitation in northern Chile, Appl. Geochem., 14, 411-422.

Brüggen, J. (1950). Fundamentos de la geología en Chile, Instituto Geográfico Militar, Santiago, 374 pp.

Capaccioni, B. and F. Mangani (2001). Monitoring of active but quiescent volcanoes using light hydrocarbon distribution in volcanic gases: the results of 4 years of discontinuous monitoring in the Campi Flegrei (Italy), Earth Planet. Sci. Lett., 188, 543-555.

Capaccioni, B., Y. Taran, F. Tassi, O. Vaselli, F. Mangani and J.L. Macias (2004). Source conditions and degradation processes of light hydrocarbons in volcanic gases: an example from El Chichón volcano (Chiapas State, Mexico), Chem. Geol., 206, 81-96.

Capaccioni, B., F. Tassi, M. Maione, F. Mangani and O. Vaselli (2005). Organics in volcanic gases: a review on their distribution and applications to volcanic surveillance, AGU Fall Meeting, 5-9 December, San Francisco, USA.

Casertano, L. (1963). General characteristics of active Andean volcanoes and a summary of their activities during recent centuries, B. Seismol. Soc. Am., 53, 1415-1433.

Céspedes, L., J. Clavero and J. Cayupi (2004). Hazard management at Isluga volcano, northern Chile: preliminary results, IAVCEI General Assembly, Pucón, Chile, 11447-a.

Chaffaut, I., A. Coudrain-Ribstein, J.L. Michelot and B. Pouyaud (1998). Précipitations d'altitude du Nord-Chile, origine des sources de vapeur et données isotopiques, Bull. Inst. Fr. Etudes Andines, 27, 367-384.

Charlou, J.L., J. P. Donval, Y. Fouquet, P. Jean-Baptiste and N. Holm (2002). Geochemistry of high $\mathrm{H}_{2}$ and $\mathrm{CH}_{4}$ vent fluids issuing from ultramafic rocks at the Rainbow hydrothermal field (36 140N, MAR), Chem. Geol., 191, 345-359.

Clavero, J., V. Soler and A. Amigo (2006). Caracterización preliminar de la actividad sísmica y de desgasificación pasiva de volcanes activos de los Andes Centrales del norte de Chile. 11th Chilean Geological Congress, Antofagasta, Chile, 443-446.

Coleman, M.L., T.J. Shepherd, J.J. Durham, J.E. Rouse and G.R. Moore (1982). Reduction of water with zinc for hydrogen isotope analysis, Anal. Chem., 54, 993-995.

Craig, H. and J.E. Lupton (1976). Primordial neon, helium, and hydrogen in oceanic basalts, Earth Planet. Sci. Lett., 31, 369-385.

Darling, W.G. (1998). Hydrothermal hydrocarbon gases: I. Genesis and geothermometry, Appl. Geochem., 13, 815-824.

de Leeuw, G.A.M., D.R. Hilton, T.P. Fischer and J.A. Walker (2007). The He- $\mathrm{CO}_{2}$ isotope and relative abundance characteristics of geothermal fluids in El Salvador and Honduras: New constraints on volatile mass balance of the Central American Volcanic Arc, Earth Planet. Sci. Lett., 258, 132-146.

Deruelle, B. (1979). Petrologie d'un volcanisme de marge active: Atacama et Andes Meridionales, PhD Thesis, Université de Paris, France.

de Silva, S.L. (1989a). Altiplano-Puna volcanic complex of the central Andes, Geology, 17, 1102-1106.

de Silva, S. L. (1989b). Geochronology and stratigraphy of the ignimbrites from the $21^{\circ} 30^{\prime}$ to $23^{\circ} 30^{\prime}$ portion of the Central Andes of Northern Chile, J. Volcanol. Geotherm. Res., 37, 93-131.

de Silva, S.L. and P. W. Francis (1991). Volcanoes of the Central Andes, Springer-Verlag, Heidelberg, $232 \mathrm{pp}$.

Des Marais, D.J. and J.G. Moore (1984). Carbon and its isotopes in mid-oceanic basaltic glasses, Earth Planet. Sci. Lett., 69, 43-57.

Epstein, S. and T.K. Mayeda (1953). Variation of the ${ }^{18} \mathrm{O} /{ }^{16} \mathrm{O}$ ratio in natural waters, Geochim. Cosmochim. Acta, 4, 213-224

Fiebig, J., G. Chiodini, S. Caliro, A. Rizzo, J. Spangenberg and J.C. Hunziker (2004). Chemical and isotopic equilibrium between $\mathrm{CO}_{2}$ and $\mathrm{CH}_{4}$ in fumarolic gas discharges: Generation of $\mathrm{CH}_{4}$ in arc magmatic-hydrothermal systems, Geochim. Cosmochim. Acta, 68, 2321-2334.

Fiebig, J., A.B. Woodland, J. Spangenberg and W. Oschmann (2007). Natural evidence for rapid abiogenic hydrothermal generation of $\mathrm{CH}_{4}$, Geochim. Cosmochim. Acta, 71, 3028-3039.

Fiebig, J., A.B. Woodland, W. D'Alessandro and W. Puttmann (2009). Excess methane in continental hydrothermal emissions is abiogenic, Geology, 37, 495-498.

Fischer, T.P., N.C. Sturchio, J. Stix, G.B. Arehart, D. Counce, S.N. Williams (1997) The chemical and isotopic composition of fumarolic gases and spring discharges 
from Galeras volcano, Colombia, J. Volcanol. Geotherm. Res., 77, 229-253.

Fu, Q., B. Sherwood Lollar, J. Horita, G. Lacrampe-Couloume and J.W.E. Seyfried (2007) Abiotic formation of hydrocarbons under hydrothermal conditions: constraints from chemical and isotopic data, Geochim. Cosmochim. Acta, 71, 1982-1998.

Francis, P.W. and D.A. Rothery (1987). Using the Landsat thematic mapper to detect and monitor active volcanoes: an example from Lascar volcano, northern Chile, Geology, 15, 614-617.

Gardeweg, M.C. and E. Medina (1994). La erupcion subpliniana del 19-20 de Abril de 1993 del Volcan Lascar, N. de Chile, 7th Chilean Geological Congress, 7, 229-304.

Gardeweg, M.C., R.S.J. Spark and S.J. Matthews (1998). Evolution of Lascar Volcano, northern Chile, J. Geol. Soc. London, 155, 89-104.

Giggenbach, W.F. (1980). Geothermal gas equilibria, Geochim. Cosmochim. Acta, 44, 2021-2032.

Giggenbach, W.F. (1987). Redox processes governing the chemistry of fumarolic gas discharges from White Island, New Zeland, Appl. Geochem., 2, 143-161.

Giggenbach, W.F. and R. L. Goguel (1989). Collection and analysis of geothermal and volcanic water and gas discharges, Unpublished report, Chemistry Division, DSIR-Petone, New Zealand, $81 \mathrm{pp}$.

Giggenbach, W.F. (1992a). The composition of gases in geothermal and volcanic systems as a function of tectonic setting, In: Water-Rock Interaction, Y.K. Kharaka and A.S. Maest editors, Balkema, Rotterdam, 2, 873-878.

Giggenbach, W.F. (1992b). Isotopic shifts in waters from geothermal and volcanic systems along convergent plate boundaries and their origin, Earth Planet. Sci. Lett., 113, 495-510.

Giggenbach, W. F. and R. Poreda (1993). Helium isotopic and chemical composition of gases from the volcanichydrothermal systems in the Philippines, Geothermics, 22, 369-380.

Giggenbach, W.F. (1996). Chemical composition of volcanic gases, In: Monitoring and mitigation of Volcanic Hazards, M. Scarpa and R.J. Tilling editors, Springer-Verlag, Berlin Heidelberg, 221-256.

Giggenbach, W.F. (1997). The origin and evolution of fluids in magmatic-hydrothermal systems, in Geochemistry of hydrothermal ore deposits H. L. Barnes editor, 3rd Edition, Wiley, 737-796.

Global Volcanism Program (1990). Olca-Paruma, Fumarolic activity and minor seismicity, BGVN 15:03; http:/ / www. volcano.si.edu.

Global Volcanism Program (1997). Irruputuncu. Volcanic Activity Reports, BGVN 22:07; http: / /www.volcano.si.edu.

González-Ferrán, O. (1995). Volcanes de Chile, Instituto Geografico Militar, Santiago, Chile, 642 pp.
Hauser, A. (1997). Catastro y caracterización de las fuentes de aguas minerales y termales de Chile, Servicio Nacional de Geología y Minería, $N^{\circ}$ 50, p. 90.

Hilton, D.R., T.P. Fischer and B. Marty (2002). Noble gases and volatile recycling at subduction zones, Rev. Mineral. Geochem., 47, 319-370.

Horita, J. and M.E. Berndt (1999). Abiogenic methane formation and isotopic fractionation under hydrothermal conditions, Science, 285, 1055-1057.

Javoy, M., F. Pineau and C.J. Allegre (1982). Carbon geodynamic cycle, Nature, 300, 171-173.

Javoy, M. and F. Pineau (1991). The volatiles record of a "popping" rock from the Mid-Atlantic Ridge at $14^{\circ} \mathrm{N}$ : chemical and isotopic composition of gas trapped in the vesicles, Earth Planet. Sci. Lett., 107, 598-611.

Kiyosu, Y., N. Asada and Y. Yoshida (1992). Origin of light hydrocarbon gases from the Matsukawa geothermal area in Japan, Chem. Geol., 94, 321-329.

Konn, C., J.L. Charlou, J.P. Donval, N.G. Holm, F. Dehairs and S. Bouillon (2009). Hydrocarbons and oxidized organic compounds in hydrothermal fluids from Rainbow and Lost City ultramafic-hosted vents, Chem. Geol., 258, 299-314.

Lewicki, J.L., T. Fischer, and S.N. Williams (2000) Chemical and isotopic compositions of fluids at Cumbal volcano, Colombia: evidence for magmatic contribution, Bull. Volcanol., 62, 347-361.

Mamyrin, B.A. and I.N. Tolstikhin (1984). Helium isotopes in nature, In: Development in geochemistry, W.S. Fyfe editor, Elsevier, Amsterdam, 274 pp.

Marinovic, N. and A. Lahsen (1984). Hoja Calama: Región de Antofagasta, escala 1:250.000, Servicio Nacional de Geología y Minería, $\mathrm{N}^{\circ}$ 58, p. 140.

Martini, M. (1993). Water and fire: Vulcano island from 1977 1991, Geochem. J., 27, 297-303.

Marty, B. and A. Jambon (1987). C/ ${ }^{3} \mathrm{He}$ in volatile fluxes from the solid earth: Implications for carbon geodynamics, Earth Planet. Sci. Lett., 83, 16-26.

Marty, B. and I.N. Tolstikhin (1998). CO $_{2}$ fluxes from mid ocean ridges, arcs and plumes, Chem. Geol., 145, 233-248.

Matsuo, S., M. Suzuki and Y. Mizutani (1978). Nitrogen to argon ratio in volcanic gases, Terrestrial rare gases, Proc. U.S.-Japan Seminar on Rare Gas Abundance and Isotopic Constraints on the Origin and Evolution of the Earth's Atmosphere, 17-25.

McCollom, T.M., B. Sherwood Lollar, G. Lacrampe-Couloume and J.S. Seewald (2010) The influence of carbon source on abiotic organic synthesis and carbon isotope fractionation under hydrothermal conditions, Geochim. Cosmochim. Acta, 74, 2717-2740.

Montegrossi, G., F. Tassi, O. Vaselli, A. Buccianti and K. Garofalo (2001). Sulfur species in volcanic gases, Anal. Chem., 73, 3709-3715.

Montegrossi, G, F. Tassi, O. Vaselli, and A. Minissale (2003). 
Heterocyclic compounds in volcanic and geothermal systems: case studied from Vulcano Island (Sicily, Italy) and Larderello (Central-Northern Italy), 4th FIST Congress, 16-18 September, Bellaria, Italy, 419-420.

Naranjo, J.A. (1992). Chemistry and petrological evolution of the Lastarria volcanic complex in the north Chilean Andes, Geol. Mag., 129, 723-740.

Oremland, R.S., L.G. Miller and M.J. Whiticar (1987). Sources and flux of natural gases from Mono Lake, California, Geochim. Cosmochim. Acta, 51, 2915-2929.

Ozima, M. and F.A. Podosek (2002). Noble Gas Geochemistry, 2nd ed., Cambridge University Press, 286 pp.

Patino, L.C., M.J. Carr and M.D. Feigenson (2000). Local and regional variations in Central American arc lavas controlled by variations in subducted sediment input, Contrib. Mineral. Petrol., 138, 265-283.

Poorter, R.P.E., J.C. Varekamp, R.J. Poreda, M.J. Vanbergen and R. Kreulen (1991). Chemical and isotopic compositions of volcanic gases from the East Sunda and Banda arcs, Indonesia, Geochim. Cosmochim. Acta, 55, 3795-3807.

Poreda, R.J., A.W.A. Jeffrey, L.R. Kaplan and H. Craig (1988). Magmatic helium in subduction-zone natural gases, Chem. Geol., 71, 199-210.

Poreda, R.J. and K.A. Farley (1992). Rare-gases in Samoan xenoliths. Earth Planet. Sci. Lett., 113, 129-144.

Proskurowski G., M.D. Lilley, J.S. Seewald, G.L. Fruh-Green, E.J. Olson, J.E. Lupton, S.P. Sylva and D.S. Kelley (2008). Abiogenic hydrocarbon production at Lost City Hydrothermal Field, Science, 319, 604-607.

Ramírez, C. and M. Gardeweg (1982). Hoja Toconao: Región de Antofagasta, escala 1:250.000, Servicio Nacional de Geología y Minería, No 54, p. 122.

Riso Patrón, L. (1924). Diccionario Jeográfico de Chile, Imprenta Universitaria, Santiago.

Rollinson, H. (1993). Using geochemical data, Longman Scientific $\&$ Technical, Essex, U.K., 352 pp.

Sano, Y. And H. Wakita (1988). Precise measurement of helium isotopes in terrestrial gases, Bull. Chem. Soc. Jpn., 61, 1153-1157.

Sano, Y. and B. Marty (1995). Origin of carbon in fumarolic gases from island arcs, Chem. Geol., 119, 2656-274.

Sano, Y. and S.N. Williams (1996). Fluxes of mantle and subducted carbon along convergent plate boundaries, Geophys. Res. Lett., 23, 2749-2752.

Schoell, M. (1988). Multiple origins of methane in the Earth, Chem. Geol., 71, 1-10.

Shaw, A.M., D.R. Hilton, T.P. Fischer, J.A. Walker and G.E. Alvarado (2003). Contrasting He-C relationships in Nicaragua and Costa Rica: insights into C cycling through subduction zones, Earth Planet. Sci. Lett., 214, 499-513.

Sherwood-Lollar, B., T.D. Westgate, J.A. Ward, G.F. Slater and G. Lacrampe-Couloume (2002). Abiogenic formation of alkanes in the Earth's crust as a minor source for global hydrocarbon reservoirs, Nature, 416, 522-524.

Sherwood Lollar, B., G. Lacrampe-Couloume, G.F. Slater, J.A. Ward, D.P. Moser, T.M. Gihring, L.H. Lin, and T.C. Onstott (2006) Unravelling abiogenic and biogenic sources of methane in the Earth's deep subsurface, Chem. Geol., 226, 328-339.

Snyder, G., R.J. Poreda, A. Hunt and U. Fehn (2001). Regional variations in volatile composition: Isotopic evidence for carbonate recycling in the Central American volcanic arc, Geochem. Geophys. Geosyst., 2; doi: 10.1029/2001GC 000163.

Snyder, G., R.J. Poreda, U. Fehn and A. Hunt (2003). Sources of nitrogen and methane in Central American geothermal settings: Noble gas and 129I evidence for crustal and magmatic volatile components, Geochem. Geophys. Geosyst., 4; doi: 10.1029/2002GC000363.

Springer, M.H. and A. Förster (1998). Heat flow density across the Central Andean subduction zone, Tectonophysics, 291, 123-139.

Stern, C. (2004). Active Andean volcanism: its geologic and tectonic setting, Rev. Geol. Chile, 31, 161-206.

Symonds, R.B., W.I. Rose, G.J.S. Bluth and T.M. Gerlach (1994). Volcanic-gas studies: Methods, Results, and applications, In: Volatiles in Magmas, M.R. Carroll and J.R. Holloway editors, Mineral. Sot. Am., 30, 1-66.

Taran, Y.A., B.G. Pokrovsky and A.D. Esikov (1989). Deutetium and oxygen-18 in fumarolic steam and amphiboles from some Kamchatka volcanoes: "andesitic waters", Dokl. Akad. Nauk SSSR, 304, 440-443.

Taran, Y.A., C.B. Connor, V.N. Shapar, A.A. Ovsyannikov and A.A. Bilichenko (1997) Fumarolic activity of Avachinsky and Koryaksky volcanoes, Kamchtka, from 1993 to 1994, Bull. Volcanol., 58, 441-448.

Taran, Y.A. and W.F. Giggenbach (2003). Geochemistry of light hydrocarbons in subduction-related volcanic and hydrothermal fluids, In: Volcanic, geothermal, and oreforming fluids: rulers and witnesses of processes within the Earth, S.F. Simmons and I.J. Graham editors, Littleton, Colo. Soc. Econ. Geol. Spec. Issue, 10, 61-74.

Taran, Y.A., G.A. Kliger and V.S. Sevastyanov (2007). Carbon isotope effects in the open-system Fischer-Tropsch synthesis, Geochim. Cosmochim. Acta, 71, 4474-4487.

Taran, Y.A., G.A. Kliger, E. Cienfuegos and A.N. Shuykin (2010). Carbon and hydrogen isotopic compositions of products of open-system catalytic hydrogenation of $\mathrm{CO}_{2}$ : Implications for abiogenic hydrocarbons in Earth's crust, Geochim. Cosmochim. Acta, 74, 6112-6125.

Tassi, F., O. Vaselli, B. Capaccioni, C. Giolito, E. Duarte, E. Fernandez, A. Minissale and G. Magro (2005a). The hydrothermal-volcanic system of Rincon de la Vieja volcano (Costa Rica): a combined (inorganic and organic) geochemical approach to understanding the origin of the fluid discharges and its possible application to volcanic 
surveillance, J. Volcanol. Geoth. Res., 148, 315-333.

Tassi, F., C. Martinez, O. Vaselli, B. Capaccioni and J. Viramonte (2005b). The light hydrocarbons as new geoindicators of equilibrium temperatures and redox conditions of geothermal fields: evidence from El Tatio (northern Chile), Appl. Geochem., 20, 2049-2062.

Tassi, F., F. Aguilera, O. Vaselli, E. Medina, D. Tedesco, A. Delgado Huertas, R.J. Poreda and S. Kojima (2009). The magmatic- and hydrothermal-dominated fumarolic system at the Active Crater of Lascar volcano, northern Chile, Bull Volcanol., 71, 171-183.

Tassi, F., F. Aguilera, T. Darrah, O. Vaselli, B. Capaccioni, R.J. Poreda and A. Delgado Huertas (2010a). Fluid geochemistry of hydrothermal systems in the Arina-Parinacota, Tarapacà and Antofagasta regions (northern Chile), J. Volcanol. Geoth. Res., 192, 1-15.

Tassi, F., G. Montegrossi, F. Capecchiacci and O. Vaselli (2010b). Origin and distribution of thiophenes and furanes in gas discharges from active Volcanoes and geothermal systems, Int. J. Mol. Sci., 11, 1434-1457.

Tedesco, D., F. Tassi, O. Vaselli, R.J. Poreda, T. Darrah, E. Cuoco and M.M. Yalire (2010). Gas isotopic signatures (He, C, and $\mathrm{Ar}$ ) in the Lake Kivu region (western branch of the East African rift system): Geodynamic and volcanological implications, J. Geophys. Res., 115, B01205; doi: 10.1029/2008JB006227.

Trumbull, R.B., R. Wittenbrink, K. Hahne, R. Emmermann, W. Büsch, H. Gerstenberger and W. Siebel (1999). Evidence for late Miocene to recent contamination of arc andesites by crustal melts in the Chilean Andes $\left(25-26^{\circ} \mathrm{S}\right)$ and its geodynamic implications, J. S. Am. Earth Sci., 12, 135-155.

Vaselli, O, F. Tassi, G. Montegrossi, B. Capaccioni and L. Giannini (2006). Sampling and analysis of fumarolic gases, Acta Vulcanol., 18, 65-76.

Vergara, H. (1978). Cuadrángulo Ujina: Región de Tarapacá, escala 1:50.000, Instituto de Investigaciones Geológicas, $\mathrm{N}^{\circ} 33$, p. 63.

Vergara, H. and A. Thomas (1984). Hoja Collacagua: Región de Tarapacá, escala 1:250.000, Servicio Nacional de Geología y Minería, n. 59, p. 79.

Whiticar, M.J. and E. Suess (1990). Hydrothermal hydrocarbon gases in the sediments of the King-George Basin, Bransfield Strait, Antarctica, Appl. Geochem., 5, 135-147.

Wörner, G., K. Hammerschimdt, F. Henjes-Kunst, J. Lezaun and H. Wilke (2000). Geochronology (40Ar/39Ar, K-Ar and He-exposure ages) of Cenozoic magmatic rocks from northern Chile $\left(18-22^{\circ} \mathrm{S}\right)$ : Implications for magmatism and tectonic evolution of the Central Andes, Revista Geológica de Chile, 27, 205-240.

\footnotetext{
${ }^{\star}$ Corresponding author: Franco Tassi, Università degli Studi di Firenze, Dipartimento di Scienze della Terra, Firenze, Italy; e-mail: franco.tassi@unifi.it.

(C) 2011 by the Istituto Nazionale di Geofisica e Vulcanologia. All rights reserved.
} 